\title{
The annual glaciohydrology cycle in the ablation zone of the Greenland ice sheet: Part 1. Hydrology model
}

\author{
William COLGAN, ${ }^{1,2}$ Harihar RAJARAM, ${ }^{3}$ Robert ANDERSON, ${ }^{4,5}$ Konrad STEFFEN, ${ }^{1,2}$ \\ Thomas PHILLIPS, ${ }^{1,6}$ Ian JOUGHIN, ${ }^{7}$ H. Jay ZWALLY, ${ }^{8}$ Waleed ABDALATI ${ }^{1,2,9}$
}

\author{
${ }^{1}$ Cooperative Institute for Research in Environmental Sciences, University of Colorado, Boulder, \\ Colorado 80309-0216, USA \\ E-mail: william.colgan@colorado.edu \\ ${ }^{2}$ Department of Geography, University of Colorado, Boulder, Colorado 80309-0260, USA \\ ${ }^{3}$ Department of Civil, Environmental, and Architectural Engineering, University of Colorado, Boulder, \\ Colorado 80309-0428, USA \\ ${ }^{4}$ Institute of Arctic and Alpine Research, UCB 450, University of Colorado, Boulder, Colorado 80309-0450, USA \\ ${ }^{5}$ Department of Geological Sciences, University of Colorado, Boulder, Colorado 80309-0399, USA \\ ${ }^{6}$ Department of Aerospace Engineering Sciences, University of Colorado, Boulder, Colorado 80309-0429, USA \\ ${ }^{7}$ Applied Physics Laboratory, University of Washington, 1013 NE 40th Street, Box 355640, Seattle, \\ Washington 98105-6698, USA \\ ${ }^{8}$ Goddard Space Flight Center, Code 971, National Aeronautics and Space Administration, Greenbelt, Maryland 20771, USA \\ ${ }^{9}$ Headquarters, National Aeronautics and Space Administration, Washington, DC 20546, USA
}

\begin{abstract}
We apply a novel one-dimensional glacier hydrology model that calculates hydraulic head to the tidewater-terminating Sermeq Avannarleq flowline of the Greenland ice sheet. Within a plausible parameter space, the model achieves a quasi-steady-state annual cycle in which hydraulic head oscillates close to flotation throughout the ablation zone. Flotation is briefly achieved during the summer melt season along a $\sim 17 \mathrm{~km}$ stretch of the $\sim 50 \mathrm{~km}$ of flowline within the ablation zone. Beneath the majority of the flowline, subglacial conduit storage 'closes' (i.e. obtains minimum radius) during the winter and 'opens' (i.e. obtains maximum radius) during the summer. Along certain stretches of the flowline, the model predicts that subglacial conduit storage remains open throughout the year. A calculated mean glacier water residence time of $\sim 2.2$ years implies that significant amounts of water are stored in the glacier throughout the year. We interpret this residence time as being indicative of the timescale over which the glacier hydrologic system is capable of adjusting to external surface meltwater forcings. Based on in situ ice velocity observations, we suggest that the summer speed-up event generally corresponds to conditions of increasing hydraulic head during inefficient subglacial drainage. Conversely, the slowdown during fall generally corresponds to conditions of decreasing hydraulic head during efficient subglacial drainage.
\end{abstract}

\section{INTRODUCTION}

In situ and remotely sensed observations (Zwally and others, 2002; Joughin and others, 2008; Shepherd and others, 2009; Bartholomew and others, 2010) have demonstrated that the surface velocity of marginal ice in West Greenland exhibits an annual velocity cycle, with peak velocities occurring during the summer melt season. Increased summer ice velocities have been interpreted to reflect enhanced basal sliding due to increased delivery of surface meltwater to the bed. Episodic supraglacial lake drainage events, which have been inferred to temporarily increase subglacial water pressure and result in brief high-velocity events, may be overlaid on this annual ice velocity cycle (Box and Ski, 2007; Das and others, 2008). While the displacement associated with surface meltwater-induced acceleration is a significant fraction of annual displacement in relatively small land-terminating glaciers such as Russell Glacier near Kangerlussuaq, it is a much smaller fraction of annual displacement in major marine-terminating outlet glaciers, such as Jakobshavn Isbræ near Ilulissat (Joughin and others, 2008). In marine-terminating glaciers, the primary seasonal driver of ice velocity is believed to be the annual advance and retreat of the tidewater terminus, which modulates glacier flow through a seasonal back-stress cycle (Meier and others, 1994; Vieli and others, 2000; Howat and others, 2005; Joughin and others, 2008). Projections of increased Greenland ice sheet surface meltwater production over the next century (Hanna and others, 2005) provide an impetus to understand the physical basis of the annual velocity cycle of the Greenland ice sheet. Recent theoretical (Schoof, 2011) and observational (Sundal and others, 2011) studies of the Greenland ice sheet suggest that future increases in surface meltwater production may result in a transition to more efficient subglacial drainage and a net decrease in basal sliding velocity.

Studies of alpine glaciers suggest that changes in basal sliding velocity are due to a combination of changes in the rate of glacier water storage (i.e. total glacier water input minus output; Fountain and Walder, 1998; Anderson and others, 2004; Bartholomaus and others, 2008) and changes in flotation fraction (the ratio of subglacial water pressure to basal ice pressure; Iken and others, 1983; Kamb and others, 1994). Thus, both the total amount of water storage, which is related to englacial water-table elevation, and its rate of change influence basal sliding velocity. This explains why 'bursts' of basal motion are associated with meltwater 


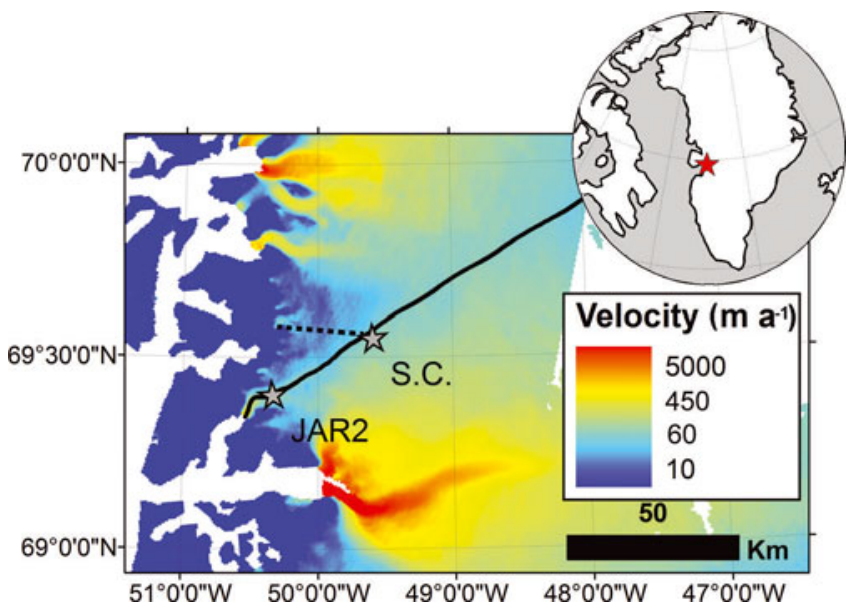

Fig. 1. The Sermeq Avannarleq flowline (black line) overlaid on winter 2005/06 interferometric synthetic aperture radar (InSAR) ice surface velocities (Joughin and others, 2010). The locations of JAR2 station and Swiss Camp are denoted with stars. The dashed line represents the shortest path to the ice-sheet margin from Swiss Camp.

'pulses', while sustained meltwater input, which eventually leads to the establishment of efficient subglacial conduits and a negative rate of change of glacier water storage, does not lead to sustained basal sliding. Changes in the rate of glacier water storage, $\mathrm{d} S / \mathrm{d} t$, are due to changes in both the rate of meltwater production (i.e. glacier 'input') and the rate of water loss from a glacier, governed by the efficiency of subglacial transmissivity via cavities and conduits (i.e. glacier 'output'). At the onset of the melt season, the initial surface meltwater input exceeds the transmissivity of the nascent subglacial system. This increases pressure in subglacial cavities and conduits, enhancing basal sliding (e.g. Fountain and Walder, 1998; Anderson and others, 2004; Bartholomaus and others, 2008). Following the onset of melt, both meltwater input and subglacial transmissivity generally increase with time, the former a direct response to meteorological forcing and the latter a response to the widening of the ice-walled conduits due to the dissipation of energy created by viscous friction (Röthlisberger, 1972; Nye, 1976). Enhanced basal sliding is maintained as long as meltwater input exceeds subglacial transmissivity (i.e. $\mathrm{d} S /$ $\mathrm{d} t>0$, or increasing hydraulic head) and is terminated once subglacial transmissivity exceeds dwindling meltwater input (i.e. $\mathrm{d} S / \mathrm{d} t<0$, or decreasing hydraulic head). A glacier may experience internal meltwater generation due to geothermal, deformational and frictional heating throughout the year. While subglacial cavities and conduits typically close or diminish in size through internal deformation following the melt season (Hock and Hooke, 1993), basal sliding may occur throughout the winter as long as internal meltwater generation exceeds subglacial transmissivity.

The desire to quantify the hydrologic contribution to enhanced summer basal sliding in the Greenland ice sheet provides an impetus to model the magnitude and temporal distribution of changes in $\mathrm{d} S / \mathrm{d} t$ within the ice sheet. In this paper, we develop a one-dimensional (1-D) hydrology model to investigate the annual hydrologic cycle of Sermeq Avannarleq. This tidewater glacier, which calves into a side arm of Jakobshavn Fiord, is located downstream of CU/ETH ('Swiss') Camp. Its ice-dynamic flowline was determined by

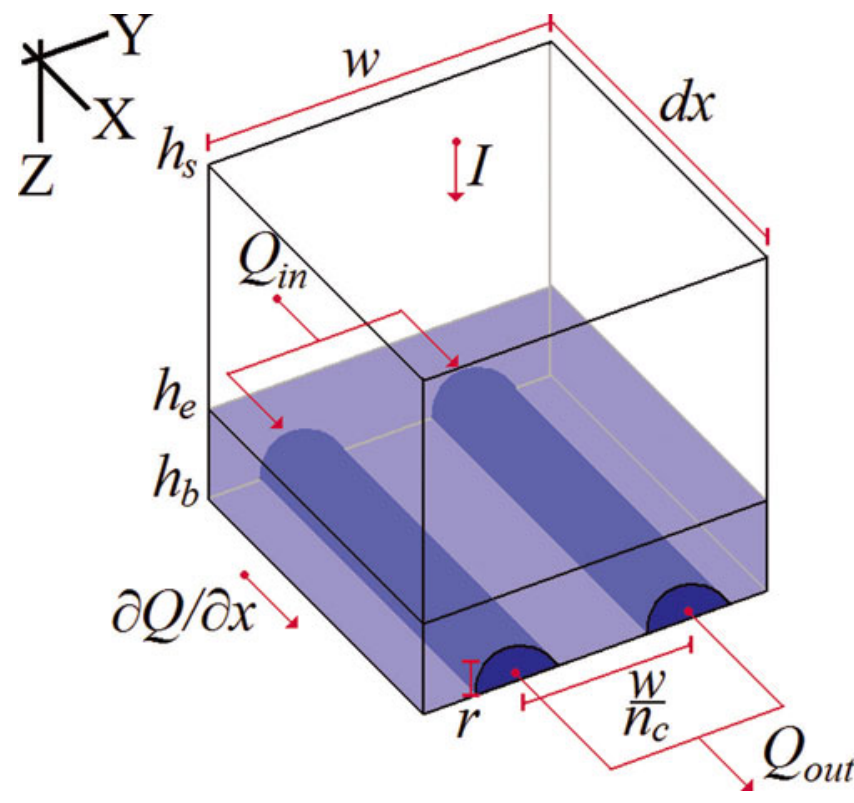

Fig. 2. Schematic of the model variables and coordinate system at a given node. Variable notation table is provided in the Appendix.

following the path of steepest ice surface slope both up- and downstream of JAR2 automatic weather station (AWS; located at $69.42^{\circ} \mathrm{N}, 50.08^{\circ} \mathrm{W}$ in 2008) using a digital elevation model (DEM) of the Greenland ice sheet, with $625 \mathrm{~m}$ horizontal grid spacing, derived from satellite altimetry and enhanced by photoclinometry (Scambos and Haran, 2002). The resultant $530 \mathrm{~km}$ flowline runs up-glacier from the tidewater terminus of Sermeq Avannarleq $(\mathrm{km} 0$ at $\left.69.37^{\circ} \mathrm{N}, 50.28^{\circ} \mathrm{W}\right)$, through JAR2 AWS (km 14), within $2 \mathrm{~km}$ of Swiss Camp ( $\mathrm{km} 46$ at $69.56^{\circ} \mathrm{N}, 49.34^{\circ} \mathrm{W}$ in 2008), to the main ice divide of the Greenland ice sheet $(\mathrm{km} 530$ at $71.54^{\circ} \mathrm{N}, 37.81^{\circ} \mathrm{W}$; Fig. 1). The tidewater tongue of Sermeq Avannarleq was stable between 1955 and 1985 (Thomsen and others, 1988). Field observations suggest that since $\sim 2000$ the tidewater tongue, currently $\sim 2 \mathrm{~km}$ long, has retreated $\sim 2 \mathrm{~km}$ and the ice surface of the terminal $\sim 5 \mathrm{~km}$ of the glacier has become increasingly crevassed.

\section{METHODS}

\subsection{Hydrology model}

We apply a 1-D (depth-integrated) hydrology model to the terminal $60 \mathrm{~km}$ of the Sermeq Avannarleq flowline to compute subglacial hydraulic head. We conceptualize the glacier hydrologic system as having perfect connectivity between the englacial and subglacial hydrologic systems (i.e. small hydraulic resistance). The assumption of hydraulic equilibrium between the englacial and subglacial systems is reasonable for capturing the seasonal timescale behavior of the glacier hydrologic system. In this conceptual model the subglacial hydraulic head is equivalent to the local englacial water-table elevation, $h_{\mathrm{e}}$. We therefore use the terms 'subglacial hydraulic head' and 'englacial water-table elevation' interchangeably. Conduits, which operate at the ice/bed interface, whose geometry evolves through time, control the horizontal water discharge, $Q$, within the glacier hydrologic system (Fig. 2). Thus, $h_{\mathrm{e}}$ varies in time and space due to variable conduit inflow and outflow as well as dynamic changes in conduit storage. As this model only has 
one horizontal layer (or 'component') representing both the englacial and subglacial systems, it can be viewed as a simplification of more advanced multicomponent models that parameterize the supraglacial, englacial, subglacial and groundwater hydrology components independently (Flowers and Clarke, 2002; Kessler and Anderson, 2004). As a consequence of not explicitly representing the supraglacial hydrologic system and the hydraulic retention time therein (i.e. firn; Fountain and Walder, 1998), surface ablation is routed instantly to the top of the englacial water table. By enforcing water conservation, the rate of change in hydraulic head (or englacial water-table elevation) at a given node along the flowline may be calculated from four terms: (1) external meltwater input, I (via both surface and basal ablation per unit area), multiplied by the flowband cross width, $w,(2)$ internal meltwater generation due to viscous melt within the conduit, $\dot{m} / \rho_{\mathrm{w}}$, (3) horizontal divergence of conduit discharge, $\partial Q / \partial x$, and (4) changes in conduit storage volume (per unit length along the flowline) through time, $\partial S_{\mathrm{C}} / \partial t$ :

$$
\phi w \frac{\partial h_{\mathrm{e}}}{\partial t}=I w+\frac{\dot{m}}{\rho_{\mathrm{w}}}-\frac{\partial Q}{\partial x}-\frac{\partial S_{\mathrm{c}}}{\partial t},
$$

where $\phi$ is the bulk ice porosity at a given node. With $w=1$, Equation (1) describes the flow per unit width along the flowline. Assuming the ice behaves like a fractured rocktype aquifer rather than a porous medium-type aquifer, this bulk ice porosity (or 'macro-porosity') is taken to represent the fractional volume occupied by fully connected surfaceto-bed discrete water-storage elements (i.e. the lumped fractional volumes of surface and basal crevasses, conduits, moulins, etc.; Flowers and Clarke, 2002). The geometry of these discrete water-storage elements remains unspecified (Kessler and Anderson, 2004). Observed values of bulk ice porosity generally range between 0.004 and 0.013 in alpine glaciers (Fountain and Walder, 1998). Similar to Kessler and Anderson (2004), we take bulk ice porosity as 0.01 and assume it is constant in space and time. We also run simulations with $\phi=0.005$ and 0.015 , the water content range constrained by ice temperature modeling of nearby Jakobshavn Isbræ (Lüthi and others, 2002).

In the conceptual framework of this model, the total water volume stored per unit length along the flowline at a given node within the glacier hydrologic system, $S$, is the sum of two terms:

$$
S=S_{\mathrm{e}}+S_{\mathrm{c}}
$$

where $S_{\mathrm{e}}$ is the englacial storage volume per unit length and $S_{\mathrm{C}}$ is the subglacial conduit storage volume per unit length. $S_{\mathrm{e}}=\phi w H_{\mathrm{e}}$, where $H_{\mathrm{e}}$ is englacial water-column thickness $\left(h_{\mathrm{e}}-h_{\mathrm{b}}\right)$. Assuming a semicircular conduit geometry, conduit storage volume per unit length (or total cross-sectional area) can be expressed as a function of conduit radius, $r$ :

$$
S_{\mathrm{C}}=\frac{\pi r^{2}}{2}\left(n_{\mathrm{C}} w\right)
$$

where $n_{\mathrm{C}}$ is the number of conduits per unit width in the cross-flow $(y)$ direction (defined in section 2.1.2).

\subsubsection{External meltwater input}

At each node along the flowline, external meltwater input, $I$, occurs as the sum of both surface ablation rate, $\dot{a}_{\mathrm{s}}$, and basal ablation rate, $\dot{a}_{\mathrm{b}}$, according to

$$
I=\dot{a}_{\mathrm{s}} F+\dot{a}_{\mathrm{b}},
$$

where $F$ is the fraction of surface meltwater that reaches the englacial water table. This external meltwater input term does not accommodate episodic supraglacial lake drainage events, which can deliver tremendous amounts of water to a single location within the glacier hydrologic system (Das and others, 2008). Rather, our interest is in the seasonal timescale response to the annual surface ablation forcing. In the ablation zone, where no firn layer exists, almost all surface meltwater can be expected to reach the glacier hydrologic system. In the accumulation zone, however, meltwater must percolate vertically through the snowpack and firn. As a result of temporary storage or refreezing during this percolation, only a fraction of surface meltwater production reaches the glacier hydrologic system (Pfeffer and others, 1991; Fountain and Walder, 1998; Janssens and Huybrechts, 2000). We approximate the englacial entry fraction based on the ratio of annual surface accumulation, $c_{\mathrm{s}}$, to annual surface ablation, $a_{\mathrm{s}}$. This formulation follows Pfeffer and others (1991), who suggest that a given fraction of the annual accumulation must melt and saturate before runoff occurs, i.e.

$$
F=1-F_{\mathrm{r}}\left(\frac{c_{\mathrm{s}}}{\left|a_{\mathrm{s}}\right|}\right) \quad \text { limit: } \mathrm{F} \geq 0 .
$$

Here $F_{\mathrm{r}}$ is the fraction of surface ablation retained in the firn where annual surface ablation and accumulation are equal. We take $F_{\mathrm{r}}$ as 0.5 , which implies that water enters the glacier hydrologic system upstream of the equilibrium line. The along-flowline profile of $F$ varies relatively little when $F_{\mathrm{r}}$ is in the range $0.3-0.7$ (Fig. 3).

We interpolate along-flowline annual surface accumulation, $c_{\mathrm{s}}$, from a previously compiled dataset (Burgess and others, 2010). Annual surface ablation, $a_{s}$ is taken as a function of elevation, based on previous in situ observations (Fausto and others, 2009), i.e.

$$
a_{\mathrm{s}}=\gamma\left(h_{\mathrm{s}}-h_{\mathrm{s}}^{\text {ela }}\right)-a_{\mathrm{s}}^{\text {ela }},
$$

where $\gamma$ is the present-day ablation gradient $\left(\Delta a_{\mathrm{s}} / \Delta h_{\mathrm{s}}\right.$, taken as 0.00372; Fausto and others, 2009) and $h_{\mathrm{s}}^{\text {ela }}$ is the equilibrium-line altitude (ELA, taken as $1125 \mathrm{~m}$ ) and $a_{\mathrm{s}}^{\text {ela }}$ is the annual surface ablation at the ELA (taken as $0.4 \mathrm{~m}$ ). Annual surface ablation is distributed through time to yield a surface ablation rate, $\dot{a}_{s}$, using a sine function to represent the melt-season solar insolation history (cf. Pimentel and Flowers, 2010):

$$
\dot{a}_{\mathrm{s}}=\frac{a_{\mathrm{s}}}{2 \pi D} \sin \left(\frac{\pi}{D}\left(j-j_{\mathrm{o}}\right)\right),
$$

where $j$ is a given Julian date (JD), $j_{\mathrm{o}}$ is the JD of melt onset (estimated as $j_{\mathrm{o}}=0.0183 h_{\mathrm{s}}+114$ ), and $D$ is the duration of the melt season (the JD of melt cessation is similarly estimated as $\left.j_{\mathrm{C}}=-0.0183 h_{\mathrm{s}}+248\right)$. While these idealized dates of melt onset and cessation lie within the observed range, this function likely underestimates the date of peak melt, which usually occurs closer to the end of the melt season (Fig. 4).

The rate of basal ablation, $\dot{a}_{b}$, is calculated as

$$
\dot{a}_{\mathrm{b}}=\frac{\left(Q_{\mathrm{d}}+Q_{\mathrm{f}}+Q_{\mathrm{g}}\right)}{\left(p_{\mathrm{i}} L\right)},
$$

where $Q_{\mathrm{d}}$ and $Q_{\mathrm{f}}$ are the heat input due to deformational (strain) and frictional heating, respectively, $Q_{g}$ is the geothermal flux, $\rho_{\mathrm{i}}$ is the density of ice $\left(917 \mathrm{~kg} \mathrm{~m}^{-3}\right)$ and $L$ is the latent heat of fusion $\left(333550 \mathrm{Jg}^{-1}\right)$. We assume a 

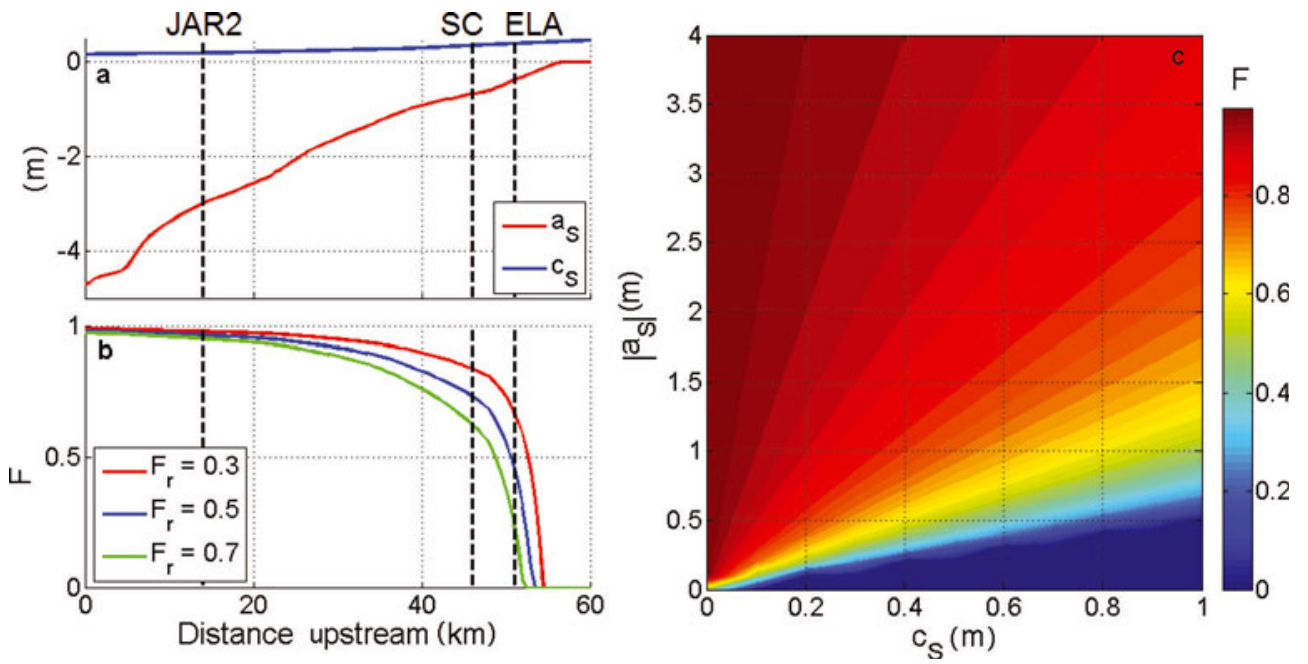

Fig. 3. (a) Observed annual surface accumulation, $c_{\mathrm{s}}$ (Burgess and others, 2010), and ablation, $a_{\mathrm{s}}$ (Fausto and others, 2009), versus

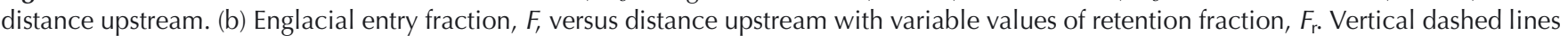
denote the locations of JAR2, Swiss Camp and the equilibrium line. (c) Englacial entry fraction (with $F_{\mathrm{r}}=0.5$ ) over the observed range of $c_{\mathrm{s}}$ and $a_{\mathrm{s}}$ values.

geothermal flux of $57 \mathrm{~mW} \mathrm{~m}^{-2}$ along the entire flowline (Sclater and others, 1980). We also assume that deformational heating is concentrated at the ice/bed interface where it contributes to basal ablation (Hooke, 2005). The lack of vertical resolution in the single-component hydrology model also necessitates that internally produced meltwater is routed instantaneously to the bed (Flowers and others, 2005). Deformational and frictional heating are calculated as

$$
Q_{\mathrm{d}}+Q_{\mathrm{f}}=\tau_{\mathrm{b}}\left(\bar{u}+u_{\mathrm{b}}\right),
$$

where $\tau_{\mathrm{b}}$ is taken as the basal gravitational driving stress, $\bar{u}$ is depth-averaged deformational ice velocity and $u_{\mathrm{b}}$ is basal sliding velocity (Hooke, 2005). Both $\tau_{\mathrm{b}}$ and $\bar{u}$ are calculated according to the shallow-ice approximation using the flow-law parameter for ice defined in section 2.1.4. As this glacier hydrology model is not currently coupled to an ice flow model that incorporates transient basal sliding velocities, we simply parameterize $u_{\mathrm{b}}$ as $15 \mathrm{ma}^{-1}$ throughout the ablation zone. Based on observations, this basal sliding velocity can be regarded as characteristic of the Sermeq

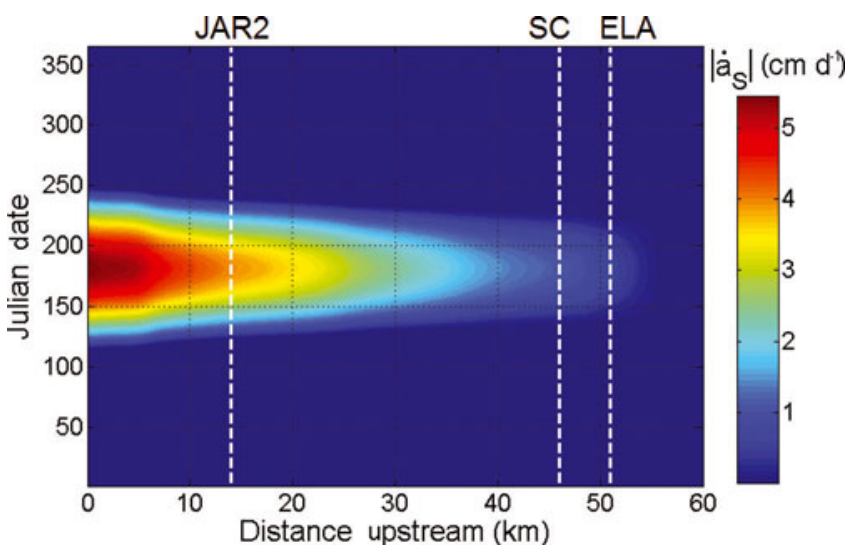

Fig. 4. The modeled time-space distribution of surface ablation rate, $\left|\dot{a}_{\mathrm{s}}\right|$. Vertical dashed lines denote the locations of JAR2, Swiss Camp and the equilibrium line.
Avannarleq ablation zone (see Colgan and others, in preparation). First-order calculations suggest that $Q_{\mathrm{f}}$ and $Q_{\mathrm{g}}$ are small compared with $Q_{\mathrm{d}}$, which makes $Q_{\mathrm{d}}$ the main control on basal ablation.

With a mean value of $3.3 \mathrm{~cm}$ (std dev. $1.6 \mathrm{~cm}$ ) in the ablation zone, annual basal ablation is a very small fraction of annual surface ablation. Beneath the $\mathrm{km} 7$ icefall, however, steep surface slopes produce a strong deformational heat flux, which results in annual basal ablation of $9.3 \mathrm{~cm}$. In comparison, annual surface ablation at the icefall is $\sim 3.5 \mathrm{~m}$. These annual basal ablation values are small compared with those estimated for Jakobshavn Isbræ, where deformational heating alone is capable of producing $>0.5 \mathrm{~m}$ of meltwater annually (Truffer and Echelmeyer, 2003). Unlike surface ablation, basal ablation is distributed evenly throughout the year. We neglect submarine basal ablation at the ice/ocean interface, as hydraulic head is prescribed as sea level within the ice tongue.

\subsubsection{Conduit discharge}

Horizontal divergence of conduit discharge, $\partial Q / \partial x$, is the along-flowline gradient in conduit discharge, $Q$. For subglacial conduits, where Reynolds numbers are expected to be large, we calculate discharge based on the DarcyWeisbach equations for turbulent flow in conduits (e.g. Röthlisberger, 1972; Nye, 1976; Spring and Hutter, 1982; Flowers and others, 2004; Pimentel and Flowers, 2010). As we assume perfect connectivity between the subglacial and englacial systems and that conduits are located at the ice/ bed interface, conduit discharge is dependent on the local hydraulic-head gradient, $\partial h_{\mathrm{e}} / \partial x$ :

$$
Q=-\left(\frac{\pi r^{2}}{2}\right) \sqrt{\frac{8 g}{f} D_{\mathrm{h}}\left|\frac{\partial h_{\mathrm{e}}}{\partial x}\right|}\left(n_{\mathrm{c}} w\right) \operatorname{sign}\left(\frac{\partial h_{\mathrm{e}}}{\partial x}\right),
$$

where $g$ is gravitational acceleration $\left(9.81 \mathrm{~m} \mathrm{~s}^{-2}\right), f$ is a friction factor, $D_{\mathrm{h}}$ is the effective hydraulic diameter, $r$ is the conduit radius, $n_{\mathrm{C}}$ is the number of conduits per meter in the cross-flow direction and $w$ is the flowband cross width. We assume a friction factor of 0.05 , which is appropriate for turbulent flow in rough-walled pipes, where the amplitude 

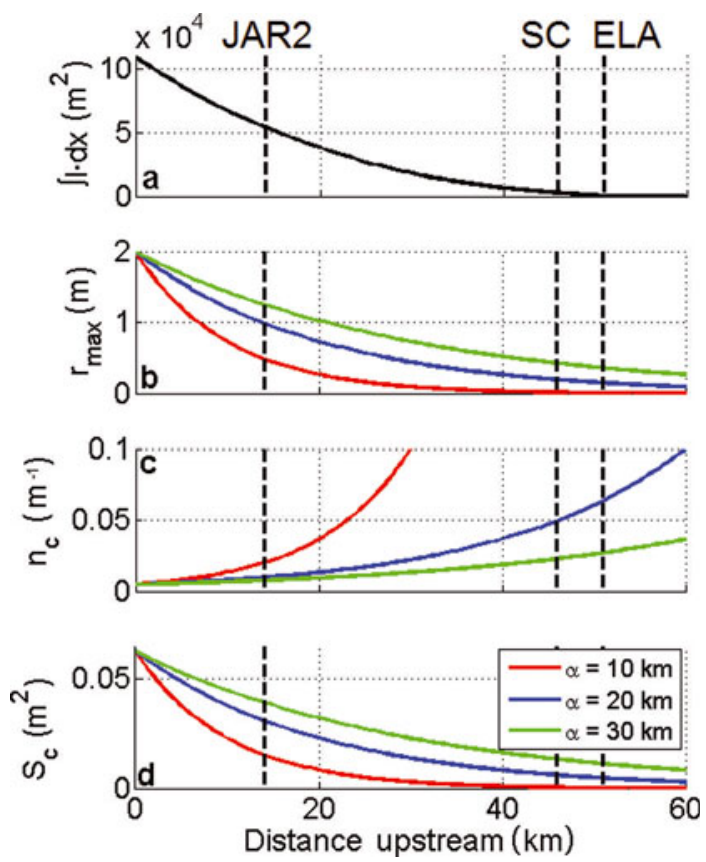

Fig. 5. (a) Total annual external meltwater input per unit width entering the glacier hydrologic system upstream of a given position $\left(\int l \cdot d x\right)$. (b) Maximum conduit radius, $r_{\max }$ (c) Conduit spacing in the across-flow direction, $n_{\mathrm{c}}$. (d) Total conduit storage volume per unit length, $S_{\mathrm{c}}$. Line color varies with glacier hydrology length scale, $\alpha$. Vertical dashed lines denote the locations of JAR2, Swiss Camp and the equilibrium line.

of the wall roughness elements is $\sim 0.02$ times the pipe diameter (Moody, 1944). To assess model sensitivity, we also present a simulation in which $f$ is taken as 0.01 .

We approximate the observed arborescent nature of subglacial conduit systems (Fountain and Walder, 1998) within the framework of our flowline model by making the number of conduits per unit width, $n_{\mathrm{C}}$, in the cross-flow $(y)$ direction an exponential function of distance upstream from the terminus, $x$ :

$$
n_{\mathrm{c}}=n_{\mathrm{c}}^{\mathrm{ter}} \exp \left(\frac{x}{\alpha}\right)
$$

where $n_{c}^{\text {ter }}$ is the number of conduits per unit width at the terminus (taken as 0.005 or $200 \mathrm{~m}$ between conduits) and $\alpha$ is a glacier hydrology length scale controlling the rate of increase in number of conduits per unit width (or the rate of decrease in spacing between conduits) with distance upstream. At any flowline position, the subglacial hydrologic system is represented as a set of non-interacting parallel conduits, with a conduit spacing given by Equation (11).

As disequilibrium between the forces promoting conduit opening and closure is permitted in the model (discussed in section 2.1.4), we must constrain conduit radii between reasonable maximum and minimum dimensions to prevent implausible feedbacks (i.e. permanent closure and unrestricted growth). The need to impose these boundaries may be attributed to the intrinsic limitations of a simplified 1-D hydrologic model. The evolving geometry of the subglacial hydrologic system can only be represented accurately with a higher-dimensional model that allows for flow divergence (convergence) away from (towards) highly conductive conduits. A model that incorporates these processes can in principle simulate conduit geometry without prescribed

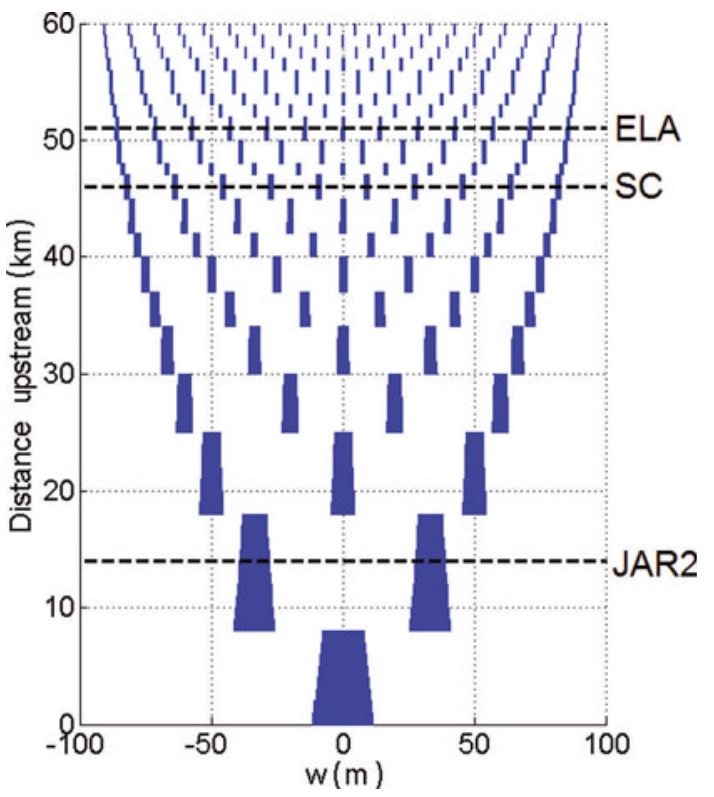

Fig. 6. Schematic of the arborescent approximation of the conduit network: number of conduits (rounded to nearest integer) and maximum conduit diameter, $2 r$ (5 times exaggerated), versus distance upstream when $\alpha=20 \mathrm{~km}$. Horizontal dashed lines denote the locations of JAR2, Swiss Camp and the equilibrium line.

upper and lower bounds for conduit radii. Higher-dimensional modelling would also benefit from a more precise characterization of the bedrock geometry throughout our study area.

Similar to conduit spacing, we also parameterize maximum conduit radius, $r_{\max }$ as an exponential function of distance upstream from the terminus:

$$
r_{\max }=r_{\max }^{\mathrm{ter}} \exp \left(\frac{-x}{\alpha}\right),
$$

where $r_{\max }^{\text {ter }}$ is the maximum permissible conduit radius at the terminus (arbitrarily taken as $2 \mathrm{~m}$ ) and $\alpha$ is the same glacier hydrology length scale as in Equation (11), which controls the rate of decrease in maximum conduit radius with distance upstream $\left(r_{\min }\right.$ is taken as $10 \%$ of $\left.r_{\max }\right)$.

On the assumption that the total conduit storage volume per unit length, $S_{c}$, at a given position along the flowline reflects the integrated annual external meltwater input per unit width that enters the glacier hydrologic system upstream of that position $\left(\int l \cdot d x\right)$, we can approximate the glacier hydrology length scale, $\alpha$, as the length scale of the along-flowline $\int I \cdot d x$ profile. A qualitative assessment suggests that $\alpha=20 \mathrm{~km}$ renders an along-flowline $S_{\mathrm{c}}$ profile that approximates the $\int I \cdot d x$ profile better than $\alpha=10$ or $30 \mathrm{~km}$ (Fig. 5). Thus, we take $\alpha=20 \mathrm{~km}$ as the glacier hydrology length scale. Together, Equations (11) and (12) capture the essence of an arborescent conduit network, namely the decrease in both conduit spacing and conduit radius with distance upstream (Fig. 6). There are, however, an infinite number of combinations of conduit spacing and radius values that may yield a given discharge, and neither parameter is tightly constrained by field observations. Thus, our maximum and minimum conduit radii may not necessarily reflect actual limits found in nature; they merely reflect limits that, together with the conduit spacing relation we have imposed, lead to reasonable values for the overall transmissivity of the conduit system. 

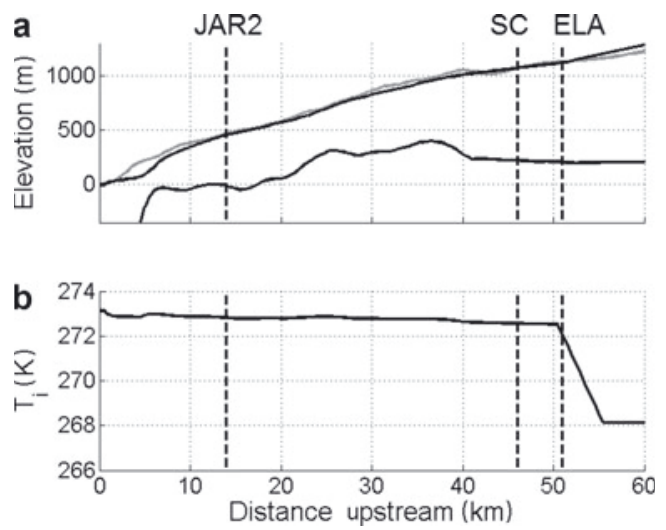

Fig. 7. (a) Modeled (black; see Colgan and others, in preparation) and observed (grey; Scambos and Haran, 2002) ice surface elevation, $h_{\mathrm{s}}$ and observed bedrock topography, $h_{\mathrm{b}}$ (Bamber and others, 2001; Plummer and others, 2008). (b) Estimated basal ice temperature, $T_{\mathrm{i}}$. Vertical dashed lines denote the locations of JAR2, Swiss Camp and the equilibrium line.

\subsubsection{Meltwater generation in conduits}

At each node along the flowline, meltwater is generated within the conduits as a consequence of the dissipation of the heat generated by viscous friction in the water; this heat is instantaneously conducted to conduit walls (Nye, 1976). The rate at which water is produced by internal melt, $\dot{m}$, in units of mass per length per time at a given node, is a function of conduit discharge, $Q$, local hydraulic-head gradient, $\partial h_{\mathrm{e}} / \partial x$, and the latent heat of fusion of ice, $L$ :

$$
\dot{m}=\frac{\rho_{\mathrm{w}} g Q}{L}\left|\frac{\partial h_{\mathrm{e}}}{\partial x}\right| .
$$

\subsubsection{Conduit volume}

As the conduits grow and shrink at each node along the flowline, the local conduit storage volume per unit length, $S_{\mathrm{c}}$ (or total cross-sectional area), changes. Conduit storage volume grows through two processes: (1) the volume per unit length created by the ice removed through internal meltwater generation $\left(\dot{m} / \rho_{\mathrm{i}}\right.$, where $\dot{m}$ is calculated according to Equation (13)), and (2) deformational opening, which occurs when water pressure, $P_{\mathrm{w}}$ (defined as $\rho_{\mathrm{w}} g H_{\mathrm{e}}$ ), exceeds ice pressure, $P_{\mathrm{i}}$ (defined as $\rho_{\mathrm{i}} g H_{\mathrm{i}}$ ). Conversely, conduit storage volume only decreases through deformational closure when $P_{\mathrm{i}}>P_{\mathrm{w}}$. Thus, our model assumes that deformational opening of conduits can occur in response to high subglacial water pressures (Nye, 1976; Ng, 2000; Clarke, 2003). As we are assuming perfect connectivity between the subglacial and englacial systems, the basal water pressure both inside and outside the conduits may be regarded as equivalent. This implicitly discounts the possibility of 'leakage' of high water pressures from the conduit system to adjacent regions (Bartholomaus and others, 2008). As basal ice temperature in the ablation zone is likely at the pressure-melting point (Phillips and others, 2010), we do not consider conduit closure through refreezing of water within the conduits. The processes that govern the transient rate of change of conduit storage volume per unit length, $\partial S_{\mathrm{C}} / \partial t$, can be expressed as (Nye, 1976)

$$
\frac{\partial S_{\mathrm{c}}}{\partial t}=\frac{\dot{m}}{\rho_{\mathrm{i}}}-2 A\left(\frac{\pi r^{2}}{2}\right)\left(n_{\mathrm{c}} w\right)\left(\frac{\left|P_{\mathrm{i}}-P_{\mathrm{w}}\right|}{n}\right)^{n} \operatorname{sign}\left(P_{\mathrm{i}}-P_{\mathrm{w}}\right),
$$

where $A$ is the temperature-dependent flow-law parameter
(Huybrechts and others, 1991) and $n$ is the Glen's law exponent $(n=3)$. We enhance the temperature-dependent flow-law parameter by a factor of three to account for softer Wisconsinan basal ice (Reeh, 1985; Paterson, 1991), which comprises the bottom $\sim 20 \%$ of the ice column along the flowline (Huybrechts, 1994).

As recent thermodynamic modeling suggests that basal ice throughout the ablation zone of the Sermeq Avannarleq flowline is at the pressure-melting point (Phillips and others, 2010), we calculate basal ice temperature, $T_{i}$, downstream of the equilibrium line as

$$
T_{\mathrm{i}}=273.15-\beta H_{\mathrm{i}}
$$

where $\beta$ is the change in melting point with ice thickness (taken as $8.7 \times 10^{-4} \mathrm{~K} \mathrm{~m}^{-1}$; Paterson, 1994). In the accumulation zone, where downward vertical ice velocities are expected to produce cold basal ice temperatures, we simply prescribe basal ice temperature as $268 \mathrm{~K}$. This is the basal ice temperature predicted just upstream of the equilibrium line by recent thermodynamic modeling (Phillips and others, unpublished information). We linearly transition from pressure-melting point basal ice temperatures in the ablation zone to the cold basal ice temperature of the accumulation zone between the equilibrium line and $5 \mathrm{~km}$ upstream of the equilibrium line. The resultant basal ice temperature profile is consistent with the notion that meltwater percolation rapidly warms the ice below the equilibrium line and captures the essence of Sermeq Avannarleq basal ice temperature profiles produced by Phillips and others (unpublished information; Fig. 7).

\subsection{Datasets and boundary conditions}

This hydrology model employs several observational datasets. Annual surface accumulation and annual surface ablation profiles were obtained from previously compiled datasets (Fausto and others, 2009; Burgess and others, 2010). Both these ice-sheet-scale surface climatology datasets use models to interpolate between in situ observations, including the four Greenland Climate Network (GC-Net) AWSs along the Sermeq Avannarleq flowline (Steffen and Box, 2001). To define ice geometry, we use a modeled ice surface elevation $\left(h_{\mathrm{s}}\right)$ profile (see Colgan and others, in preparation), which compares well with the profile interpolated from a DEM of the Greenland ice sheet derived from satellite altimetry enhanced by photoclinometry (Scambos and Haran, 2002; Fig. 7). A coarse-resolution bedrock elevation $\left(h_{\mathrm{b}}\right)$ dataset is available along the entire flowline (Bamber and others, 2001). While this dataset has nominal $5 \mathrm{~km}$ horizontal resolution, actual resolution is dependent on the spacing of airborne flight-lines, and thus varies spatially and can exceed $5 \mathrm{~km}$. A finer-resolution dataset (nominally $750 \mathrm{~m}$ ) is available for the terminal $40 \mathrm{~km}$ of the flowline (Plummer and others, 2008).

Equipotential englacial hydraulic-head gradients are theoretically $\sim 11$ times more sensitive to ice surface slopes than bedrock slopes (Shreve, 1972). Thus, first-order ice surface slope (i.e. regional or $\sim 10$ ice thicknesses) may be expected to govern the first-order geometry of subglacial flow direction. For example, the water beneath Swiss Camp can be expected to travel $\sim 30 \mathrm{~km}$ to the ice-sheet margin on an azimuth of $\sim 279^{\circ}$ (i.e. following regional ice surface slope; dashed line in Fig. 1). By forcing subglacial water to flow along the ice-dynamic flowline to the margin (i.e. following steepest local or $\sim 1$ ice thickness surface slope), 


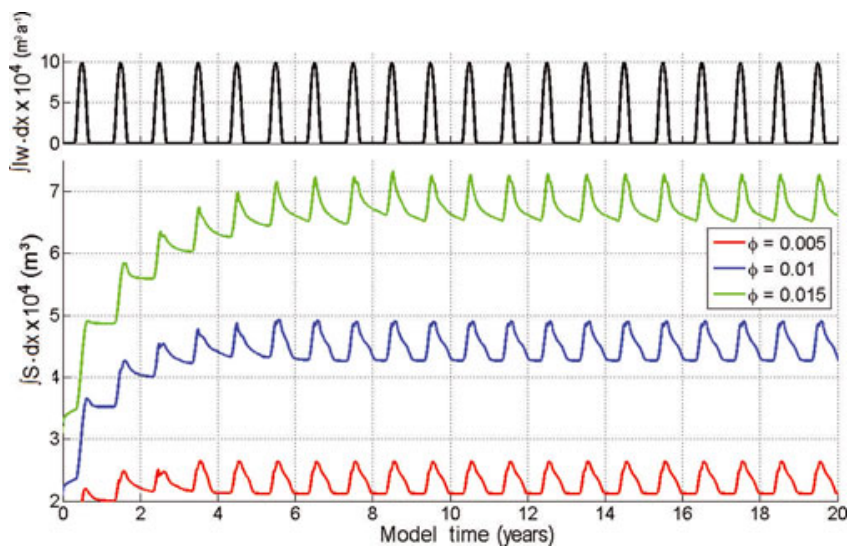

Fig. 8. Total flowline prescribed external water input, $\int I w \cdot d x$ $\left(\mathrm{m}^{3} \mathrm{a}^{-1}\right)$, and total flowline modeled water storage, $\int S \cdot \mathrm{d} x$, for various values of bulk ice porosity, $\phi$, during 20 year simulations.

subglacial water is routed $\sim 48 \mathrm{~km}$ on an azimuth of $\sim 225^{\circ}$. This artificially reduces the hydraulic-head gradient, $\partial h_{\mathrm{e}} / \partial x$, by artificially increasing $d x$. To compensate for this we use simple trigonometry to project the dynamic flowline on the hydrologic coordinates, correcting $\mathrm{d} x$ values on a node-bynode basis, and thereby maintaining realistic $\partial h_{\mathrm{e}} / \partial x$ values along the length of the flowline.

We apply first-type (specified head) Dirichlet boundary conditions to hydraulic head, $h_{\mathrm{e}}$. From $\mathrm{km0}$ to 2 , the tidewater terminus, $h_{\mathrm{e}}$ is prescribed as sea level (i.e. $\left.h_{\mathrm{e}}=0 \mathrm{~m}\right)$. We use the cold-to-warm basal ice temperature transition at the equilibrium line ( $\mathrm{km} \mathrm{51)} \mathrm{to} \mathrm{approximate} \mathrm{the}$ upstream limit of the glacier hydrologic system. We impose a no-flux boundary that extends upwards from the bedrock beneath the equilibrium line to the ice surface at 11 times the local surface slope. This is the steepest theoretical gradient that water traveling through the ice sheet could be expected to take in order to reach the bed at the cold-to-warm basal ice temperature transition beneath the equilibrium line (Shreve, 1972). Thus, upstream of the equilibrium line, there is a portion of the glacier hydrologic system that behaves as a 'perched' aquifer (i.e. underlain by cold ice). In this $\sim 4 \mathrm{~km}$ portion of the flowline, we assume that ice temperature is sufficiently heterogeneous to allow the persistence of englacial conduits (Catania and Neumann, 2010). We treat the discharge of these conduits in an identical manner to the conduits downstream of the equilibrium line, except we suspend the processes that govern the transient rate of change of conduit storage volume, $\partial S_{\mathrm{C}} / \partial t$, and prescribe conduit radii as constant $(5 \mathrm{~cm})$. We assume that any water entering the ice upstream of the intersection of the perched aquifer and the ice surface refreezes, although we do not perform a full enthalpy solution to incorporate this process as a transient flux. We also assume that basal ablation is zero beneath the cold basal ice in the accumulation zone. The glacier hydrologic system is therefore fully transient over the $49 \mathrm{~km}$ between the equilibrium line $(\mathrm{km} \mathrm{51})$ and the tidewater terminus $(\mathrm{km} 2)$.

The differential equations describing transient hydraulic head, $\partial h_{\mathrm{e}} / \partial t$, were discretized in space using first-order finitevolume methods $(\mathrm{d} x=500 \mathrm{~m})$ with hydraulic head, $h_{\mathrm{e}}$, at cell centers and fluxes, $Q$, at cell edges. The semi-discrete set of ordinary differential equations coupled at the computational nodes was then solved using 'ode15s', the stiff differential equation solver in MATLAB R2008b, with a 1 day time-step.

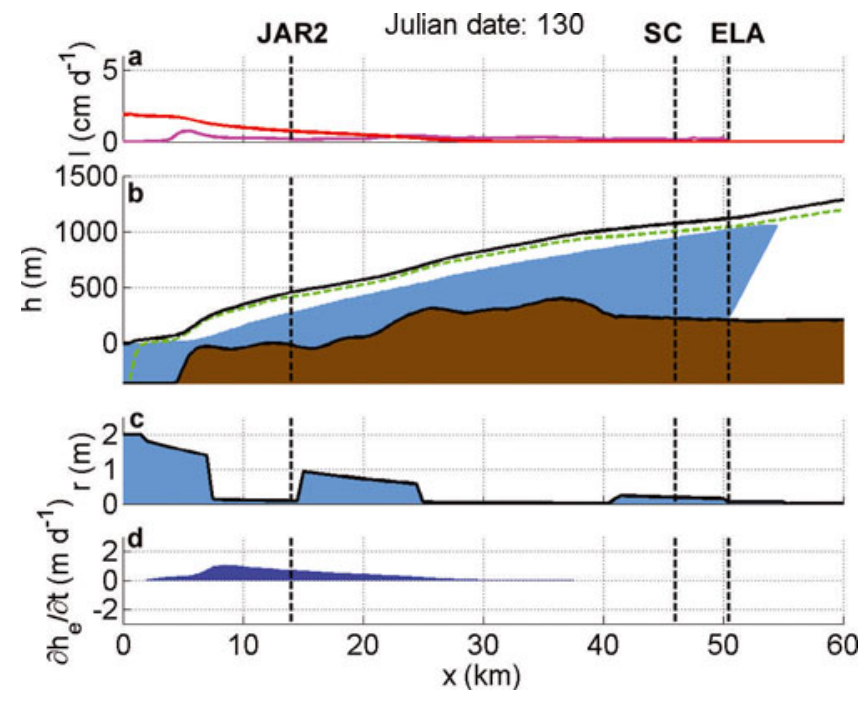

Animation 1. Modeled hydrology along the terminal $60 \mathrm{~km}$ of the Sermeq Avannarleq flowline. (a) External meltwater input, I; both surface (red; $a_{\mathrm{s}} F$ ) and basal ablation (magenta; ab; $30 \times$ exaggerated). (b) Ice surface elevation ( $h_{\mathrm{s}}$; white), bedrock elevation $\left(h_{\mathrm{b}} ;\right.$ brown) and hydraulic head (or englacial water-table elevation; $h_{\mathrm{e}} ;$ blue). Dashed green line represents the hydraulic head equal to flotation. (c) Conduit radius, $r$. (d) Rate of change in hydraulic head, $\partial h_{\mathrm{e}} / \partial h_{\mathrm{t}}$. Vertical dashed lines identify the positions of JAR2, Swiss Camp and the equilibrium line. Full movie available at www. igsoc.org/hyperlink/10J154_Animation1.mov.

\section{RESULTS}

The 1-D hydrology model achieves a quasi-steady-state annual cycle in hydraulic head after $\sim 7$ years of spin-up (Fig. 8; Animation 1). Generally, modeled flotation fraction, $P_{\mathrm{w}} / P_{\mathrm{i}}$, increases with distance upstream to a maximum at the equilibrium line (Fig. 9). Upstream of the equilibrium line, where basal ice temperatures are assumed to transition from warm to cold, the englacial hydrologic system likely behaves as a perched aquifer where it becomes underlain by cold ice. In this region, the high englacial water-table elevation should not be interpreted as a high flotation fraction, because this water pressure is not exerted at the

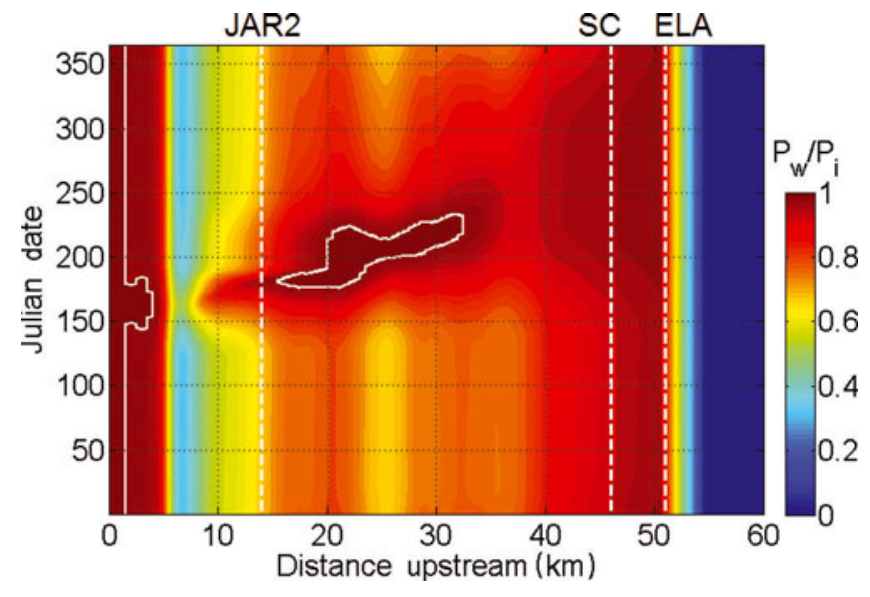

Fig. 9. Modeled time-space distribution of flotation fraction, $P_{\mathrm{w}} / P_{\mathrm{i}}$. The white contour denotes a flotation fraction of 1 . Vertical dashed lines denote the locations of JAR2, Swiss Camp and the equilibrium line. 

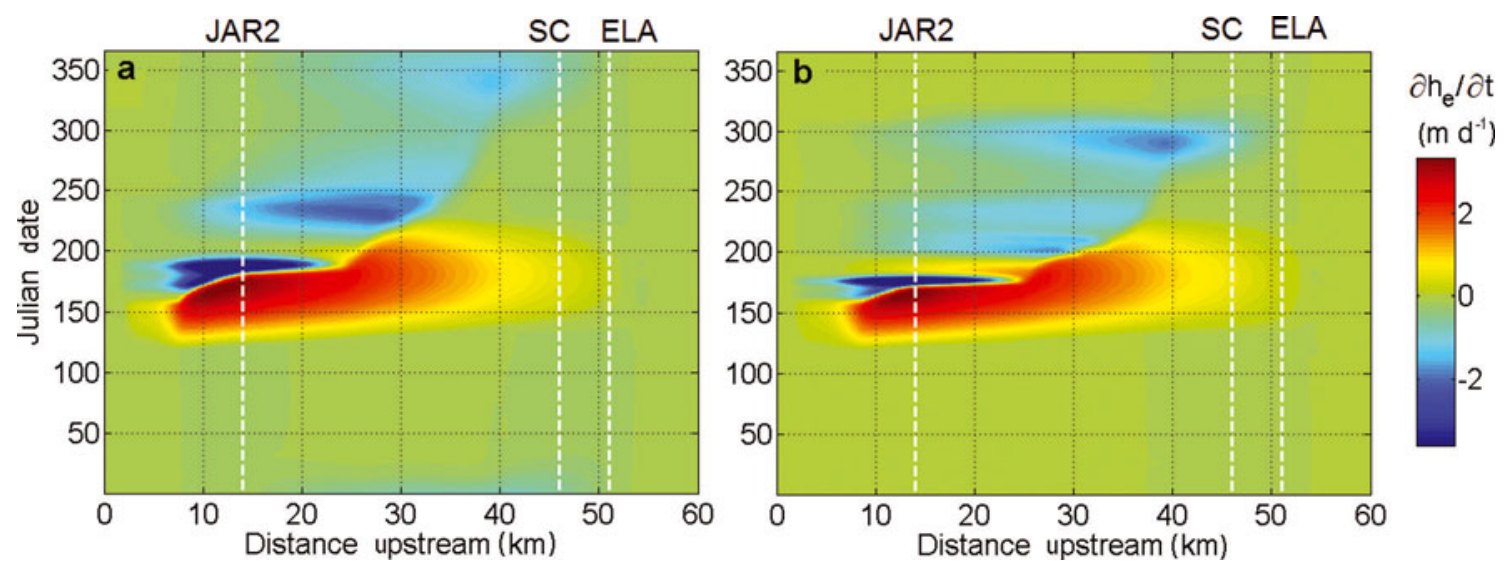

Fig. 10. Modeled time-space distribution of the rate of change of hydraulic head (or englacial water-table elevation; $\partial h_{\mathrm{e}} / \partial t$ ) when conduit friction factor, $f$, equals 0.05 (a) and 0.01 (b). Color bar saturates below $-3.6 \mathrm{~m} \mathrm{~d}^{-1}$. Vertical dashed lines denote the locations of JAR2, Swiss Camp and the equilibrium line.

bed. In fact, in this region, we assume that no subglacial water is present and hence subglacial water pressure should be zero. The $\sim 2 \mathrm{~km}$ tidewater tongue remains at flotation year-round (i.e. $P_{\mathrm{w}} / P_{\mathrm{i}}=1$ ). In response to meltwater input from surface ablation, flotation fraction exhibits a broad summer peak throughout the ablation zone. This peak occurs progressively later with distance upstream, due to the upstream migration of surface ablation inputs. The modeled hydraulic head fluctuates relatively close to flotation throughout the year; flotation is achieved for a brief period between $\mathrm{km} 16$ and 33 .

The time-space pattern of the rate of change in hydraulic head, $\partial h_{\mathrm{e}} / \partial t$ (a proxy for the rate of change in glacier water storage, $\mathrm{d} S / \mathrm{d} t)$, may be conceptualized as the derivative of the time-space pattern of flotation fraction (when the condition $\partial S_{\mathrm{c}} / \partial t \ll \partial S_{\mathrm{e}} / \partial t$ is satisfied; Fig. 10). The entire flowline experiences positive rates of glacier water storage (or increasing hydraulic head) at the beginning of the melt season (as high as $3.6 \mathrm{md}^{-1}$ ), and negative rates of glacier water storage (or decreasing hydraulic head) at the end of the melt season (as low as $-10.2 \mathrm{~m} \mathrm{~d}^{-1}$ ). Generally, the total water volume stored along the flowline decreases (or drains) more slowly than it increases (or fills; Fig. 8). The magnitude of the modeled annual $\partial h_{\mathrm{e}} / \partial t$ cycle decreases with distance upstream, reaching approximately zero in the vicinity of the equilibrium line (taken as the upstream boundary of temperate basal ice and the englacial hydrologic system). The transition from positive to negative rates of storage also progressively lags with distance upstream. Unlike the positive rates of glacier water storage, which exhibit a smooth time-space distribution, the negative rates of glacier water storage have a more patchy time-space distribution, with certain dates and flowline locations experiencing anomalously fast or slow negative rates of glacier water storage. This is a consequence of the evolution of the subglacial conduit system.

Modeled subglacial conduit storage exhibits sharp alongflowline boundaries between regions of closed and opened conduits (i.e. $\mathrm{km} \mathrm{7,} \mathrm{16,} \mathrm{25,} 42$ and 50; Animation 1). This suggests two types of subglacial environments exist: (1) 'yearround' (i.e. km 16-25 and 42-50) and (2) 'seasonally' (i.e. km 7-16 and 25-42) open subglacial conduit storage. Following the onset of surface ablation, conduits begin to grow upstream from the tidewater terminus (where conduits are open year-round due to a lack of deformational closure pressure in the floating tidewater tongue). When a stretch of seasonally open subglacial conduit storage connects to an upstream stretch of year-round open subglacial conduit storage, there is a temporary anomalously large negative rate of water storage (i.e. decrease in local hydraulic head) as the portion of the flowline underlain by the year-round conduits is drained relatively quickly. Subsequently, the upstream stretch of seasonally open subglacial conduit storage begins to open (due to an increase in local hydraulic-head gradient) and the negative rate of water storage returns to a smaller magnitude. The opening of seasonal conduits that serve to connect stretches of year-round conduit storage are responsible for the patchy time-space distribution of negative rates of glacier water storage.

\section{DISCUSSION}

\subsection{Hydrology model}

Based on the absolute value of flotation fraction, as well as qualitative features in the annual hydraulic-head cycle (i.e. a positive phase followed by a negative phase with no significant change during the winter), we conclude that the relatively simple one-component 1 -D hydrology model produces a reasonable annual hydrologic cycle along the terminal $60 \mathrm{~km}$ of the Sermeq Avannarleq flowline. The modeled hydraulic head oscillates close to flotation throughout the ablation zone of the Sermeq Avannarleq flowline. The suggestion of a relatively high englacial water table is consistent with previous in situ observations of flotation fractions between 0.79 and 1.05 in the Paakitsoq area $\left(69.5^{\circ} \mathrm{N}, 50.0^{\circ} \mathrm{W}\right.$; Thomsen and Olesen, 1991) and between 0.95 and 1.00 in Jakobshavn Isbræ $\left(69.2^{\circ} \mathrm{N}\right.$, $48.7^{\circ} \mathrm{W}$; Iken and others, 1993; Lüthi and others, 2002). The high modeled flotation fraction along the flowline is due to the dependence of conduit conductivity and discharge on the relative difference between water and ice pressures. Sufficiently high hydraulic head is needed to overcome basal ice pressure and open the conduits. Once open, conduits draw down hydraulic head until reaching a threshold below which hydraulic head is no longer sufficient to counteract basal ice pressure and keep the conduits open. The conduits subsequently close, achieving 


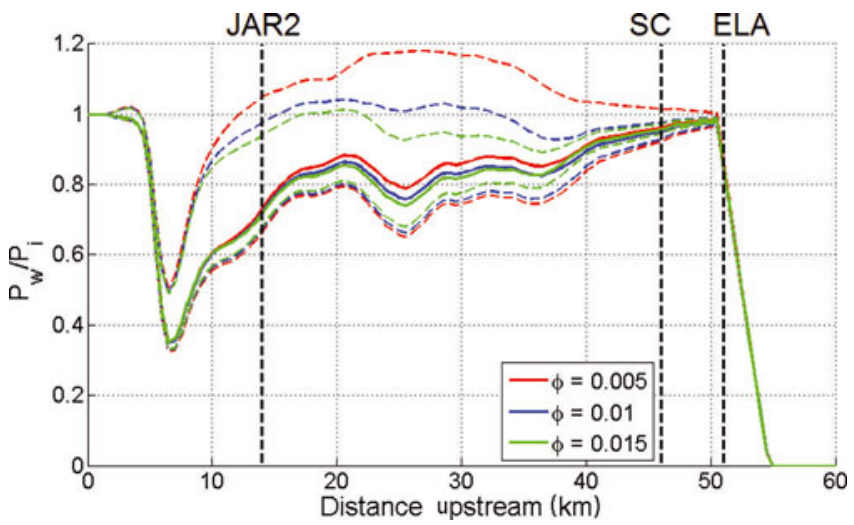

Fig. 11. Mean annual flotation fraction, $P_{\mathrm{w}} / P_{\mathrm{i}}$, versus distance upstream for various values of bulk ice porosity, $\phi$. Dashed curves represent annual maximum and minimum values. Vertical dashed lines denote the locations of JAR2, Swiss Camp and the equilibrium line.

their minimum prescribed radius, $r_{\min }$, leaving large amounts of residual water stored in the glacier.

Model runs in which bulk ice porosity, $\phi$, is taken as 0.005 and 0.015 return very similar along-flowline profiles of mean annual flotation fraction (Fig. 11). Thus, a relatively high hydraulic head is likely an inherent feature of a glacier hydrologic system drained solely by conduits. The alongflowline profile of maximum flotation fraction is, however, higher (lower) in the lower (higher) bulk ice porosity simulation. Thus, as currently parameterized, the magnitude of $\partial h_{\mathrm{e}} / \partial t$ is a function of bulk ice porosity. When $\phi=0.005$, flotation fraction values are unrealistically high in the vicinity of $\mathrm{km} 25$ ( $\sim 1.2$ which is conducive to artesian springs). Bulk ice porosity values as low as 0.0005 have been postulated for alpine glaciers (Humphrey and others, 1986). Our sensitivity analysis suggests that increased water storage at the bed must be invoked to produce realistic flotation fraction values when $\phi \ll 0.01$. At present, our single-component model does not explicitly incorporate the water storage volume created at the ice/bed interface by vertical uplift of the ice sheet (cf. Pimentel and Flowers, 2010). Due to this limitation a portion of the bulk ice porosity can be assumed to represent the storage volume of discrete voids at the ice/bed interface. In reality, the storage volume at the ice/bed interface is likely a function of hydraulic head, rather than constant in space and time as we have implicitly assumed by using constant porosity.

The model inference of year-round subglacial conduit storage along certain portions of the flowline $(\mathrm{km} \mathrm{16-25}$ and 42-50) is supported by limited observations of the persistence of some englacial hydrology features through the winter in the Sermeq Avannarleq ablation zone (Catania and Neumann, 2010). The sharp model transitions between yearround and seasonally active conduit storage appear to be due to slight changes in the along-flowline gradient in local hydraulic head, $\partial h_{\mathrm{e}} / \partial x$; subglacial conduit storage volume per unit length, $S_{\mathrm{c}}$ is proportional to the magnitude of $\left(\partial h_{\mathrm{e}}\right)$ $\partial x)^{1.5}$. When a bedrock topography that increases monotonically upstream is imposed, the pockets of year-round subglacial conduit storage form in the same location as when the observed bedrock topography is imposed (Animation 2). As short stretches of year-round subglacial conduit storage appear to form downstream of stretches of relatively
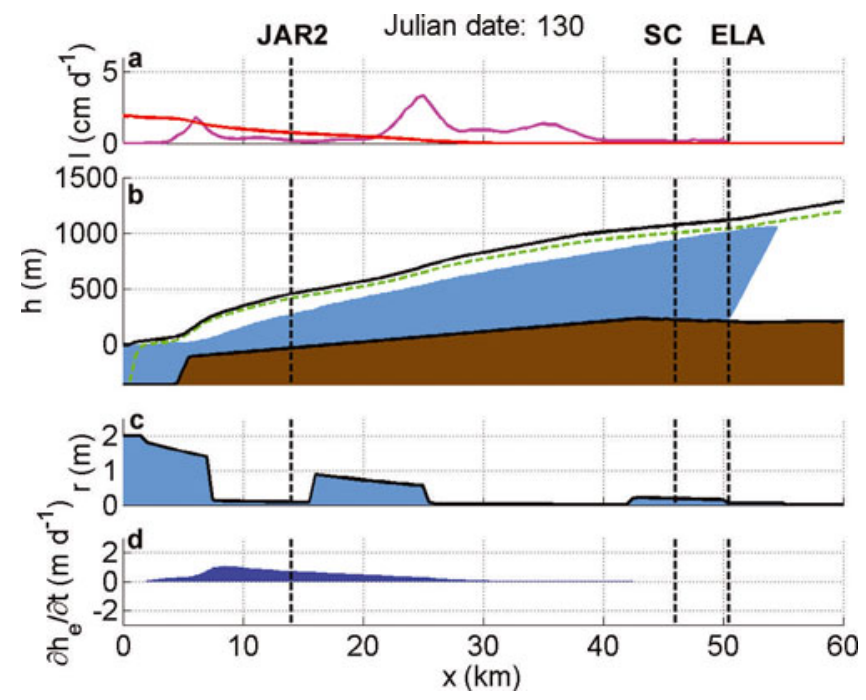

Animation 2. Same as Animation 1 except with a modified bedrock topography that increases monotonically upstream. Full movie available at www.igsoc.org/hyperlink/10J154_Animation2.mov.

steep ice surface topography, we speculate that the alongflowline gradient in ice surface elevation, $\mathrm{d} h_{\mathrm{s}} / \mathrm{d} x$, influences the along-flowline gradient in local hydraulic head, $\partial h_{\mathrm{e}} / \partial x$, and hence the location of year-round subglacial conduit storage. When an ice surface topography with sinusoidal undulations (25 $\mathrm{m}$ amplitude and $10 \mathrm{~km}$ wavelength) is imposed, the pockets of year-round subglacial conduit storage tend to form beneath portions of the flowline with the steepest ice surface slopes (Animation 3). Along-flowline gradients in flotation fraction, $P_{\mathrm{w}} / P_{\mathrm{i}}$, as a result of ice surface topography may also have an influence in the location of year-round subglacial conduit storage. Maintaining yearround subglacial conduit storage through deformational opening, however, could only be expected along portions of the flowline where water pressure exceeds ice pressure yearround. The time-space distribution of modeled flotation fraction suggests that this only occurs in the tidewater tongue ( $\mathrm{km} \mathrm{0-2;} \mathrm{Fig.} \mathrm{9).} \mathrm{The} \mathrm{model} \mathrm{inference} \mathrm{that} \mathrm{portions} \mathrm{of}$ the subglacial conduit storage system may overwinter at the base of the Greenland ice sheet to be reactivated the following melt season differs slightly from previous alpine glacier work, which suggests a new channelized subglacial hydrologic system migrates up-glacier from the terminus each melt season (Hubbard and Nienow, 1997).

During the period of peak decreasing hydraulic head at Swiss Camp (i.e. JD 300 or 325, depending on $f$ parameterization; Fig. 10) the conduits draw down hydraulic head with the efficiency of a semicircular conduit $40 \mathrm{~cm}$ in diameter spaced every $20 \mathrm{~m}$ and operating at basal ice and water pressure (i.e. $n_{\mathrm{C}}=0.050 \mathrm{~m}$ and $r=0.20 \mathrm{~m}$ ). Similarly, during the period of peak decreasing hydraulic head at JAR2 ( JD 180) the conduit system is parameterized to discharge water with the efficiency of a semicircular conduit $1.98 \mathrm{~m}$ in diameter spaced every $100 \mathrm{~m}$ operating at basal ice and water pressure $\left(n_{\mathrm{c}}=0.010 \mathrm{~m}\right.$ and $\left.r=0.99 \mathrm{~m}\right)$. Although our parameterized conduit system appears to be reasonable, a lack of field observations makes this configuration speculative. The choice of conduit friction factor, $f$, which is a measure of resistance (discharge is inversely related to $f$ ), appears to influence the timing, but not magnitude, of negative $\partial h_{\mathrm{e}} / \partial t$ values (Fig. 10). A smaller 

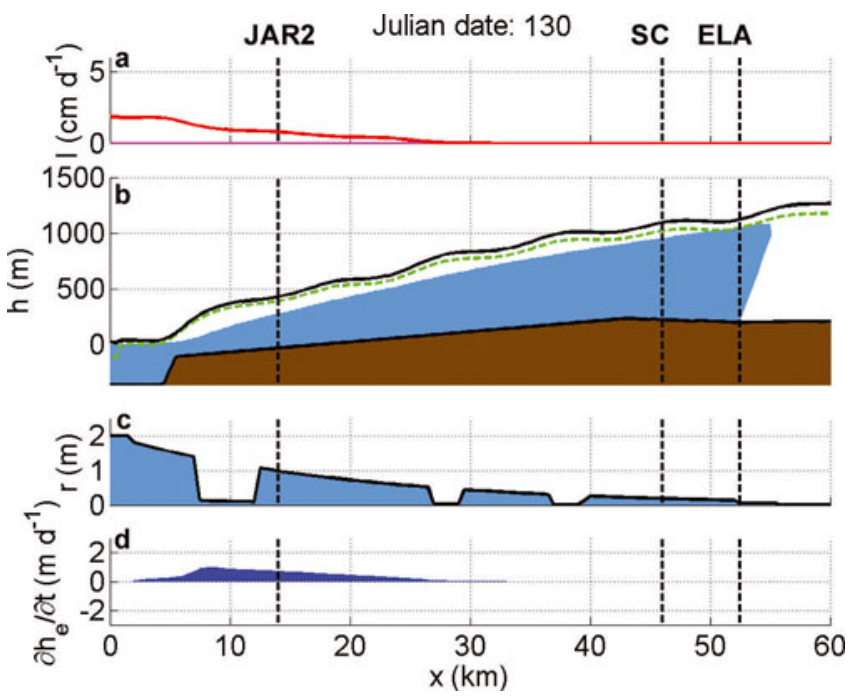

Animation 3. Same as Animation 2 except with a sinusoidal pattern (25 $\mathrm{m}$ amplitude and $10 \mathrm{~km}$ wavelength) imposed on ice surface topography and basal ablation actively disabled. Full movie available at www.igsoc.org/hyperlink/10J154_Animation3.mov.

value of $f$ propagates the perturbation in hydraulic-head gradient responsible for conduit opening upstream more quickly than a larger value of $f$.

Assuming a bulk ice porosity of 0.01 , and that the modeled glacier hydrologic cycle is in quasi-steady state, the mean residence time, $t_{\text {res, }}$ of water in the flowline can be calculated as $\sim 2.2$ years, when $w=1 \mathrm{~m}$, according to

$$
t_{\text {res }}=\frac{\int S \cdot d x}{\int I w \cdot d x}
$$

where $\int S \cdot \mathrm{d} x$ is the total flowline modeled water storage (annual mean $\approx 45000 \mathrm{~m}^{3}$ ) and $\int \mathrm{I} w \cdot \mathrm{d} x$ is the total flowline prescribed external water input (annual mean $\approx 20000 \mathrm{~m}^{3} \mathrm{a}^{-1}$; Fig. 8). The integral notation $\left(\int \cdot \mathrm{d} x\right)$ refers to integration of continuous values over the entire length of flowline (i.e. all $x$ values). Assuming bulk ice porosities of 0.005 and 0.015 , the mean residence times are $\sim 1.1$ and 3.3 years, respectively. This relatively short residence time suggests that the glacier hydrologic system can be expected to respond to external meltwater forcings on a relatively short timescale (i.e. years rather than decades).

\subsection{Relevance to basal sliding}

In section 1 we reviewed the notion that variations in basal sliding velocity can be attributed to variations in the rate of change of glacier water storage (i.e. $\mathrm{d} S / \mathrm{d} t$ ) in alpine glaciers (Kamb and others, 1994; Fountain and Walder, 1998; Anderson and others, 2004; Bartholomaus and others, 2008). This conceptual model of basal sliding has recently been extended to the Greenland ice sheet (Bartholomew and others, 2010). Below we present both remotely sensed and in situ velocity data from the Sermeq Avannarleq flowline that suggest that observed periods of enhanced basal sliding generally correspond to modeled periods of positive rates of change in glacier water storage (or increasing hydraulic head), while periods of reduced basal sliding conversely correspond to modeled periods of negative rates of change in glacier water storage (or decreasing hydraulic head).

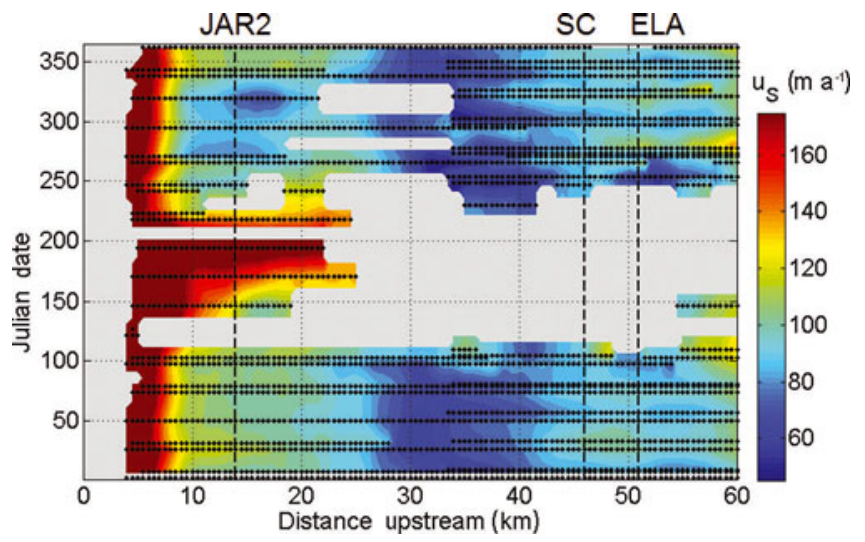

Fig. 12. Annual ice surface velocity cycle along the terminal $60 \mathrm{~km}$ of the Sermeq Avannarleq flowline (color bar saturates at $175 \mathrm{~m} \mathrm{a}^{-1}$ ). Dotted black lines indicate individual InSAR velocity profiles. Vertical dashed lines denote the locations of JAR2, Swiss Camp and the equilibrium line.

Given the proximity of Sermeq Avannarleq to Jakobshavn Isbræ, multiple 2005 and 2006 interferometric synthetic aperture radar (InSAR)-derived ice surface velocity profiles are available for the terminal $60 \mathrm{~km}$ of the Sermeq Avannarleq flowline (Joughin and others, 2008). Linear interpolation between these profiles yields a time-space velocity plot (Fig. 12). While summer velocities are not available upstream of $\mathrm{km} 22$, the region around JAR2 exhibits a distinct annual velocity cycle. This cycle consists of a summer speed-up event, in which velocities exceed winter velocity, followed by a fall slowdown event, in which velocities decrease to lower than winter velocity. These observed velocity anomalies may be interpreted as periods of enhanced and suppressed basal sliding that qualitatively correspond to periods of modeled increasing and decreasing hydraulic head.

High-frequency differential GPS measurements have been acquired at Swiss Camp since June 1996, providing daily resolution of the annual ice surface velocity cycle for the last 12 years (Larson and others, 2001; Zwally and others, 2002; Fig. 13). In accordance with the InSAR observations, these in situ GPS observations reveal that the ice at Swiss Camp also experiences a summer speed-up event, in which ice velocities increase above winter velocities, followed by a fall slowdown event, in which ice velocities decrease below winter velocities. The summer speed-up event varies in peak magnitude and timing over the 12 year record, presumably due to variable surface climatology and meltwater forcing, as well as local supraglacial lake drainage events. While the model is not forced with an observed melt history, the modeled period of increasing hydraulic head (i.e. JD 150-200) generally matches the timing of the observed speed-up event. The observed slowdown event, however, follows the observed speed-up event in relatively quick succession. The modeled peak in decreasing hydraulic head lags the modeled peak in increasing hydraulic head by 125-150 days (depending on the value of $f$; Fig. 10).

We speculate that this apparent delay in the negative $\partial h_{\mathrm{e}} /$ $\partial t$ phase, which is due to a delay in opening the upstream conduits, is a consequence of 1-D hydrological modeling. A two-dimensional (2-D; $x y$ ) hydrological model would better capture changes in englacial water-table gradient at Swiss 


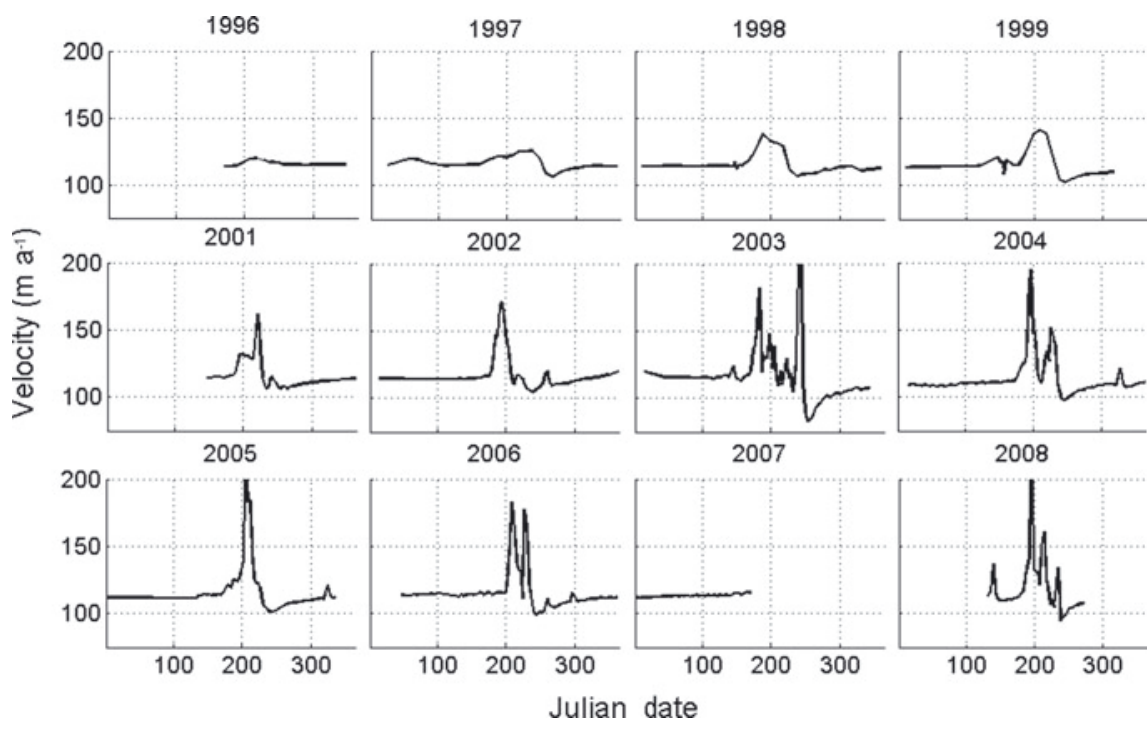

Fig. 13. Observed GPS annual velocity cycle at Swiss Camp over the 1996-2008 period.

Camp by allowing conduit discharge both parallel and perpendicular to the ice-dynamic flowline. Presently, by forcing water to flow along the entire ice-dynamic flowline to the terminus, the $1-\mathrm{D}$ model essentially requires the perturbation in local hydraulic head gradient that initiates conduit opening to slowly migrate from the terminus upstream to Swiss Camp. In reality, the glacier hydrologic system near Swiss Camp is governed by both along- and across-flow hydraulic head gradients $\left(\partial h_{\mathrm{e}} / \partial x\right.$ and $\partial h_{\mathrm{e}} / \partial y$ respectively). A 2-D ( $x y)$ model would better represent the influence of bedrock topography on subglacial discharge, by allowing subglacial discharge to concentrate in topographic low points (Shreve, 1972; Flowers and others, 2005). Due to this concentration of discharge, 2-D models are inherently more capable of developing larger and more efficient conduits than 1-D models.

Based on the qualitative agreement between observations of a strong annual ice velocity cycle and the modeled annual glacier hydrologic cycle, we propose that the terminal $50 \mathrm{~km}$ of the Greenland ice sheet's Sermeq Avannarleq flowline behaves akin to an alpine glacier, whereby the summer speed-up event is caused by inefficient subglacial drainage and positive rates of change of glacier water storage (i.e. $\mathrm{d} S / \mathrm{d} t>0$, or increasing hydraulic head), while the fall slowdown event reflects the establishment of efficient subglacial drainage and negative rates of change of glacier water storage (i.e. $\mathrm{d} S / \mathrm{d} t<0$, or decreasing hydraulic head). A notable departure from the alpine analogy, however, is the model inference that subglacial conduit storage may be capable of overwintering beneath the Greenland ice sheet to be reactivated the following melt season, rather than migrating up-glacier from the terminus each melt season as observed in alpine glaciers (Hubbard and Nienow, 1997). The recovery of both basal sliding velocities and rates of change of hydraulic head, $\partial h_{\mathrm{e}} / \partial t$, to winter values shortly after the fall slowdown, suggests that the glacier hydrologic system is capable of repressurizing to maintain winter sliding. Presumably, this occurs by: (1) a reduction in transmissivity due to conduit closure and (2) continued meltwater input, largely via basal ablation due to geothermal, frictional and deformation (strain) heat fluxes rather than internal meltwater generation, $\dot{m} / \rho_{\mathrm{w}}$.

\section{SUMMARY REMARKS}

We developed a relatively simple one-component 1-D hydrology model to track glacier water storage and discharge through time. In this model, glacier water input is prescribed based on observed ablation rates, while glacier water output occurs through conduit discharge. Conduit discharge varies in response to the dynamic evolution of conduit radius. The hydrology model suggests that subglacial hydraulic head (or, equivalently in this model, englacial water-table elevation) annually oscillates relatively close to flotation, even reaching flotation for brief periods along certain stretches of the flowline. This is consistent with the few available borehole observations of englacial watertable elevation. Alternatively imposing idealized bedrock and ice surface topographies suggests that along-flowline gradients in ice surface elevation (or ice surface slope), rather than along-flowline gradients in bedrock elevation (or bedrock slope), control the locations of year-round subglacial conduit storage. The sharp transitions between subglacial environments that support year-round and seasonally open subglacial conduit storage are likely due to slight along-flowline changes in the local englacial hydraulic head gradient. A calculated mean glacier water residence time of $\sim 2.2$ years implies that large amounts of water are stored in the glacier throughout the year. The glacier hydrologic system can therefore be expected to respond to external meltwater forcings (i.e. reorganize) on a relatively short timescale. A qualitative comparison between the observed annual ice velocity cycle and the modeled annual cycle of glacier water storage suggests that enhanced (suppressed) basal sliding occurs during periods of positive (negative) rates of glacier water storage. Thus, we speculate that the terminal $50 \mathrm{~km}$ of the Sermeq Avannarleq flowline likely experiences a basal sliding regime similar to that of an alpine glacier. Considering the inherent limitations of 1-D modeling, the timing of the modeled increasing and decreasing hydraulic-head events is also reasonable. Work is underway to produce a 2-D version of this hydrology model, which removes the need for a prescribed conduit geometry and allows a more refined characterization of the annual hydrologic cycle in the Sermeq Avannarleq region and other portions of the Greenland ice sheet. 


\section{ACKNOWLEDGEMENTS}

This work was supported by NASA Cryospheric Science Program grants NNX08AT85G and NNX07AF15G to K.S. W.C. thanks the Natural Sciences and Engineering Research Council of Canada for support through a Post-Graduate Scholarship, and the Cooperative Institute for Research in Environmental Sciences for support through a Graduate Research Fellowship. We thank J. Saba for meticulous processing of the Swiss Camp GPS data. We greatly appreciate the efforts of G. Flowers and an anonymous reviewer whose detailed comments tremendously improved the manuscript. H. Fricker was our dedicated scientific editor.

\section{REFERENCES}

Anderson, R.S. and 6 others. 2004. Strong feedbacks between hydrology and sliding of a small alpine glacier. J. Geophys. Res., 109(F3), F03005. (10.1029/2004JF000120.)

Bamber, J.L., R.L. Layberry and S.P. Gogineni. 2001. A new ice thickness and bed data set for the Greenland ice sheet. 1. Measurement, data reduction, and errors. J. Geophys. Res., 106(D24), 33,773-33,780.

Bartholomaus, T.C., R.S. Anderson and S.P. Anderson. 2008. Response of glacier basal motion to transient water storage. Nature Geosci., 1(1), 33-37.

Bartholomew, I., P. Nienow, D. Mair, A. Hubbard, M.A. King and A. Sole. 2010. Seasonal evolution of subglacial drainage and acceleration in a Greenland outlet glacier. Nature Geosci., 3(6), 408-411.

Box, J.E. and K. Ski. 2007. Remote sounding of Greenland supraglacial melt lakes: implications for subglacial hydraulics. J. Glaciol., 53(181), 257-265.

Burgess, E.W. and 6 others. 2010. A spatially calibrated model of annual accumulation rate on the Greenland Ice Sheet (19582007). J. Geophys. Res., 115(F2), F02004. (10.1029/ 2009JF001293.)

Catania, G.A. and T.A. Neumann. 2010. Persistent englacial drainage features in the Greenland Ice Sheet. Geophys. Res. Lett., 37(2), L02501. (10.1029/2009GL041108.)

Clarke, G.K.C. 2003. Hydraulics of subglacial outburst floods: new insights from the Spring-Hutter formulation. J. Glaciol., 49(165), 299-313.

Das, S.B. and 6 others. 2008. Fracture propagation to the base of the Greenland Ice Sheet during supraglacial lake drainage. Science, 320(5877), 778-781.

Fausto, R.S., A.P. Ahlstrøm, D. van As, C.E. Bøggild and S.J. Johnsen. 2009. A new present-day temperature parameterization for Greenland. J. Glaciol., 55(189), 95-105.

Flowers, G.E. and G.K.C. Clarke. 2002. A multicomponent coupled model of glacier hydrology: 1. Theory and synthetic examples. J. Geophys. Res., 107(B11), 2287. (10.1029/2001JB001122.)

Flowers, G.E., H. Björnsson, R. Pálsson and G.K.C. Clarke. 2004. A coupled sheet-conduit mechanism for jökulhlaup propagation. Geophys. Res. Lett., 31(5), L05401. (10.1029/2003GL019088.)

Flowers, G.E., S.J. Marshall, H. Björnsson and G.K.C. Clarke. 2005. Sensitivity of Vatnajökull ice cap hydrology and dynamics to climate warming over the next 2 centuries. J. Geophys. Res., 110(F2), F02011. (10.1029/2004JF000200.)

Fountain, A.G. and J.S. Walder. 1998. Water flow through temperate glaciers. Rev. Geophys., 36(3), 299-328.

Hanna, E., P. Huybrechts, I. Janssens, J. Cappelen, K. Steffen and A. Stephens. 2005. Runoff and mass balance of the Greenland ice sheet: 1958-2003. J. Geophys. Res., 110(D13), D13108. (10.1029/2004JD005641.)

Hock, R. and R.LeB. Hooke. 1993. Evolution of the internal drainage system in the lower part of the ablation area of Storglaciären, Sweden. Geol. Soc. Am. Bull., 105(4), 537-546.
Hooke, R.LeB. 2005. Principles of glacier mechanics. Second edition. Cambridge, etc., Cambridge University Press.

Howat, I.M., I. Joughin, S. Tulaczyk and S. Gogineni. 2005. Rapid retreat and acceleration of Helheim Glacier, east Greenland. Geophys. Res. Lett., 32(22), L22502. (10.1029/2005GL024737.)

Hubbard, B. and P. Nienow. 1997. Alpine subglacial hydrology. Quat. Sci. Rev., 16(9), 939-955.

Humphrey, N., C. Raymond and W. Harrison. 1986. Discharges of turbid water during mini-surges of Variegated Glacier, Alaska, U.S.A. J. Glaciol., 32(111), 195-207.

Huybrechts, P. 1994. The present evolution of the Greenland ice sheet: an assessment by modelling. Global Planet. Change, 9(1-2), 39-51.

Huybrechts, P., A. Letréguilly and N. Reeh. 1991. The Greenland ice sheet and greenhouse warming. Global Planet. Change, 3(4), 399-412.

Iken, A., H. Röthlisberger, A. Flotron and W. Haeberli. 1983. The uplift of Unteraargletscher at the beginning of the melt season a consequence of water storage at the bed? J. Glaciol., 29(101), 28-47.

Iken, A., K. Echelmeyer, W. Harrison and M. Funk. 1993. Mechanisms of fast flow in Jakobshavns Isbræ, West Greenland: Part I. Measurements of temperature and water level in deep boreholes. J. Glaciol., 39(131), 15-25.

Janssens, I. and P. Huybrechts. 2000. The treatment of meltwater retardation in mass-balance parameterizations of the Greenland ice sheet. Ann. Glaciol., 31, 133-140.

Joughin, I., S.B. Das, M.A. King, B.E. Smith, I.M. Howat and T. Moon. 2008. Seasonal speedup along the western flank of the Greenland Ice Sheet. Science, 320(5877), 781-783.

Joughin, I., B.E. Smith, I.M. Howat, T. Scambos and T. Moon. 2010. Greenland flow variability from ice-sheet-wide velocity mapping. J. Glaciol., 56(197), 415-430.

Kamb, B., H. Engelhardt, M.A. Fahnestock, N. Humphrey, M. Meier and D. Stone. 1994. Mechanical and hydrologic basis for the rapid motion of a large tidewater glacier. 2. Interpretation. J. Geophys. Res., 99(B8), 15,231-15,244.

Kessler, M.A. and R. Anderson. 2004. Testing a numerical glacial hydrological model using spring speed-up events and outburst floods. Geophys. Res. Lett., 31(18), L18503. (10.1029/ 2004GL020622.)

Larson, K.M., J. Plumb, J. Zwally and W. Abdalati. 2001. Analysis of GPS data collected on the Greenland ice sheet. Polar Geogr., 25(1), 22-40.

Lüthi, M., M. Funk, A. Iken, S. Gogineni and M. Truffer. 2002. Mechanisms of fast flow in Jakobshavn Isbræ, West Greenland. Part III. Measurements of ice deformation, temperature and cross-borehole conductivity in boreholes to the bedrock. J. Glaciol., 48(162), 369-385.

Meier, M. and 9 others. 1994. Mechanical and hydrologic basis for the rapid motion of a large tidewater glacier. 1. Observations. J. Geophys. Res., 99(B8), 15,219-15,229.

Moody, L.F. 1944. Friction factors for pipe flow. Trans. ASME, 66(8), 671-684

Ng, F.S.L. 2000. Canals under sediment-based ice sheets. Ann. Glaciol., 30, 146-152.

Nye, J.F. 1976. Water flow in glaciers: jökulhlaups, tunnels and veins. J. Glaciol., 17(76), 181-207.

Paterson, W.S.B. 1991. Why ice-age ice is sometimes 'soft'. Cold Reg. Sci. Technol., 20(1), 75-98.

Paterson, W.S.B. 1994. The physics of glaciers. Third edition. Oxford, etc., Elsevier.

Pfeffer, W.T., M.F. Meier and T.H. Illangasekare. 1991. Retention of Greenland runoff by refreezing: implications for projected future sea level change. J. Geophys. Res., 96(C12), 22,117-22,124

Phillips, T., H. Rajaram and K. Steffen. 2010. Cryo-hydrologic warming: a potential mechanism for rapid thermal response of ice sheets. Geophys. Res. Lett., 37(20), L20503. (10.1029/ 2010GL044397.) 
Pimentel, S. and G.E. Flowers. 2010. A numerical study of hydrologically driven glacier dynamics and subglacial flooding. Proc. R. Soc. London, Ser. A, 467(2126), 537-558.

Plummer, J., S. Gogineni, C. van der Veen, C. Leuschen and J. Li. 2008. Ice thickness and bed map for Jakobshavn Isbræ. Lawrence, KA, University of Kansas. Center for Remote Sensing of Ice Sheets. (Tech. Rep. 2008-1.)

Reeh, N. 1985. Was the Greenland ice sheet thinner in the Late Wisconsinan than now? Nature, 317(6040), 797-799.

Röthlisberger, H. 1972. Water pressure in intra- and subglacial channels. J. Glaciol., 11(62), 177-203.

Scambos, T.A. and T. Haran. 2002. An image-enhanced DEM of the Greenland ice sheet. Ann. Glaciol., 34, 291-298.

Schoof, C. 2011. Ice-sheet acceleration driven by melt supply variability. Nature, 468(7325), 803-806.

Sclater, J.G., C. Jaupart and D. Galson. 1980. The heat flow through oceanic and continental crust and the heat loss of the Earth. Rev. Geophys. Space Phys., 18(1), 289-311.

Shepherd, A., A. Hubbard, P. Nienow, M. McMillan and I. Joughin. 2009. Greenland ice sheet motion coupled with daily melting in late summer. Geophys. Res. Lett., 36(1), L01501. (10.1029/ 2008GL035758.)

Shreve, R.L. 1972. Movement of water in glaciers. J. Glaciol., 11(62), 205-214.

Spring, U. and K. Hutter. 1982. Conduit flow of a fluid through its solid phase and its application to intraglacial channel flow. Int. J. Eng. Sci., 20(2), 327-363.

Steffen, K. and J. Box. 2001. Surface climatology of the Greenland ice sheet: Greenland Climate Network 1995-1999. J. Geophys. Res., 106(D24), 33,951-33,964.

Sundal, A.V., A. Shepherd, P. Nienow, E. Hanna, S. Palmer and P. Huybrechts. 2011. Melt-induced speed-up of Greenland ice sheet offset by efficient subglacial drainage. Nature, 469(7331), 521-524.

Thomsen, H.H. and O.B. Olesen. 1991. Hydraulics and hydrology on the Inland Ice. Grønl. Geol. Unders. Rapp. 152, 36-38.

Thomsen, H.H., L. Thorning and R.J. Braithwaite. 1988. Glacierhydrological conditions on the Inland Ice north-east of Jacobshavn/Ilulissat, West Greenland. Grønl. Geol. Unders. Rapp. 138.

Truffer, M. and K.A. Echelmeyer. 2003. Of isbræ and ice streams. Ann. Glaciol., 36, 66-72.

Vieli, A., M. Funk and H. Blatter. 2000. Tidewater glaciers: frontal flow acceleration and basal sliding. Ann. Glaciol., 31, 217-221.

Zwally, H.J., W. Abdalati, T. Herring, K. Larson, J. Saba and K. Steffen. 2002. Surface melt-induced acceleration of Greenland ice-sheet flow. Science, 297(5579), 218-222.

\section{APPENDIX}

\section{Variable notation}

$\alpha \quad$ Glacier hydrology length scale (m)

$\beta \quad$ Change in melting point with ice thickness $\left(\mathrm{K} \mathrm{m}^{-1}\right)$

$\gamma \quad$ Ablation gradient

$\phi \quad$ Bulk ice porosity

$\rho_{\mathrm{i}} \quad$ Density of ice $\left(\mathrm{kg} \mathrm{m}^{-3}\right)$

$\rho_{\mathrm{w}} \quad$ Density of water $\left(\mathrm{kg} \mathrm{m}^{-3}\right)$ $\tau_{\mathrm{b}}$

A

$D$

$D_{\mathrm{h}}$ $F$

\section{$F_{\mathrm{r}}$}

$H_{\mathrm{e}}$

$H_{\mathrm{i}}$

I

$L$

$P_{\mathrm{i}}$

$P_{\mathrm{w}}$

$Q$

$Q_{\mathrm{d}}$

$Q_{\mathrm{f}}$

$Q_{\mathrm{g}}$

\section{$S$}

$S_{\mathrm{C}}$

$S_{\mathrm{e}}$

$T_{\mathrm{i}}$

$\dot{a}_{b}$

$a_{\mathrm{s}}$

$a_{\mathrm{s}}$
$\dot{a}_{\mathrm{s}}$

$a_{\mathrm{s}}$
$c_{\mathrm{s}}$

$C_{\mathrm{S}}$
$\dot{C}_{\mathrm{S}}$

$C_{\mathrm{S}}$
$f$

$f$

g

$h_{\mathrm{b}}$

$h_{\mathrm{e}}$

$h_{\mathrm{s}}$

j

$j_{\mathrm{c}}$

jo

$\dot{m}$

$n$

$n_{\mathrm{C}}$

$r$

$r_{\text {max }}$

$r_{\text {min }}$

$u_{\mathrm{b}}$

$u_{\mathrm{s}}$

$\bar{u}$

w

X
Gravitational driving stress (Pa)

Flow law parameter $\left(\mathrm{Pa}^{-3} \mathrm{a}^{-1}\right)$

Melt-season duration (days)

Effective hydraulic diameter (m)

Entry fraction

Retention fraction

Englacial water thickness (m)

Ice thickness (m)

Rate of external meltwater input $\left(\mathrm{m} \mathrm{a}^{-1}\right)$

Latent heat of fusion of ice $\left(\mathrm{J} \mathrm{kg}^{-1}\right)$

Ice pressure $(\mathrm{Pa})$

Water pressure $(\mathrm{Pa})$

Conduit discharge $\left(\mathrm{m}^{3} \mathrm{a}^{-1}\right)$

Heating due to deformation (strain) $\left(\mathrm{W} \mathrm{m}^{-2}\right)$

Heating due to friction $\left(\mathrm{W} \mathrm{m}^{-2}\right)$

Geothermal flux $\left(\mathrm{W} \mathrm{m}^{-2}\right)$

Total storage per unit length $\left(\mathrm{m}^{2}\right)$

Subglacial conduit storage volume per unit length $\left(\mathrm{m}^{2}\right)$

Englacial storage volume per unit length $\left(\mathrm{m}^{2}\right)$

Basal ice temperature $(\mathrm{K})$

Basal ablation rate $\left(\mathrm{m} \mathrm{a}^{-1}\right)$

Annual surface ablation $(\mathrm{m})$

Surface ablation rate $\left(\mathrm{m} \mathrm{a}^{-1}\right)$

Annual surface accumulation (m)

Surface accumulation rate $\left(\mathrm{m} \mathrm{a}^{-1}\right)$

Conduit friction factor

Gravitational acceleration $\left(\mathrm{m} \mathrm{s}^{-2}\right)$

Bedrock elevation $(\mathrm{m})$

Hydraulic head (or englacial water-table elevation) (m)

Ice surface elevation (m)

Given Julian date (day)

Julian date of melt cessation (day)

Julian date of melt onset (day)

Conduit meltwater production $\left(\mathrm{kg} \mathrm{m}^{-1} \mathrm{~s}^{-1}\right)$

Glen law exponent

Conduits per meter in the cross-flow direction $\left(\mathrm{m}^{-1}\right)$

Conduit radius $(\mathrm{m})$

Maximum conduit radius (m)

Minimum conduit radius $(\mathrm{m})$

Basal sliding velocity $\left(\mathrm{m} \mathrm{a}^{-1}\right)$

Ice surface velocity $\left(\mathrm{m} \mathrm{a}^{-1}\right)$

Depth-averaged ice velocity $\left(\mathrm{m} \mathrm{a}^{-1}\right)$

Cross-flow width (m)

Distance upstream from terminus $(\mathrm{m})$

MS received 8 September 2010 and accepted in revised form 26 March 2011 